\title{
Credit Ratings and Earnings Management around IPOs
}

\author{
Dimitrios Gounopoulos, Hang Pham ${ }^{1}$
}

\section{Forthcoming: Journal of Business Finance and Accounting}

\begin{abstract}
This study examines the impact of having a credit rating on earnings management (EM) through accruals and real activities manipulation by initial public offering (IPO) firms. We find that firms going public with a credit rating are less likely to engage in income-enhancing accrual-based and real EM in the offering year. The monitoring by a credit rating agency (CRA) and the reduced information asymmetry due to the provision of a credit rating disincentivise rated issuers from managing earnings. We also suggest that the participation of a reputable auditing firm is crucial for CRAs to effectively restrain EM. Moreover, we document that for unrated issuers, at-issue income-increasing EM is not linked to future earnings and negatively related to post-issue long-run stock performance. However, for rated issuers, at-issue income-increasing EM is positively associated with subsequent accounting performance and unrelated to long-run stock performance following the offering. The evidence indicates that managers in unrated firms generally manipulate earnings to mislead investors, while managers in rated firms tend to exercise their accounting and operating discretion for informative purposes.
\end{abstract}

JEL classification: G10, G14, G24, G3

Keywords: IPOs; Credit ratings; Earnings management

\footnotetext{
${ }^{1}$ We are grateful to Ozlem Arikan, Kevin Chan, Francois Derrien, Quintao Fan, Michael Firth, John Forker, Guanming He, Trevor Hopper, Bikki Jaggi, Arthur Kraft, David Marginson, Paul McGuinness, Patricia O’Brien, Zulfiqar Shah, Douglas Skinner, Martin Walker (The Editor), Georgios Voulgaris,, conference participants at the American Accounting Association Annual Meeting 2015, the European Accounting Association 2015, the FMA Meeting 2015, and seminar participants at the University of Leeds and the University of Sussex and the University of Warwick for valuable comments and suggestions. This study is based on a chapter of Hang Pham's thesis submitted to the University of Sussex in July 2016. Dimitrios Gounopoulos is at the Newcastle University Business School, Newcastle University, Newcastle upon Tyne, NE1 4SE, UK. Hang Pham is at the School of Business, Management and Economics, University of Sussex, Brighton BN1 9SL, UK. Corresponding author: Dimitrios Gounopoulos (email: Dimitrios.Gounopoulos@newcastle.ac.uk).
} 


\section{INTRODUCTION}

Earnings are a crucial indicator of firm performance, as investors commonly rely on them to value stocks. Consequently, managers have strong motives to manipulate earnings to influence shortterm stock prices. The incentives of managers are stronger around IPOs due to the high level of information asymmetry between inside managers and outside investors. Various studies investigating $\mathrm{EM}$ in the IPO markets find evidence of income-increasing EM around IPOs and a negative association between at-issue EM and post-issue long-run stock performance, suggesting that managers can mislead investors to opportunistically manage earnings (Aharony et al. 1993; Friedlan 1994; Teoh et al. 1998a; Teoh et al. 1998b; Roosenbloom and Van De Goot 2003; DuCharme et al. 2004; Gramlich and Sorensen 2004). The accounting research also demonstrates that certain parties, such as audit committees, boards of directors, external auditors, venture capitalists, and underwriters, can restrain EM (Becker et al. 1998; Klein 2002; Morsfield and Tan 2006; Lee and Masulis 2011). However, to our knowledge, the influence of CRAs on EM by IPO firms has not been explored.

We hypothesise that CRAs disincentivise IPO issuers from engaging in EM through their two main economic functions as an information intermediary and a monitor. By acting as an information intermediary, CRAs provide an independent assessment of the creditworthiness of a borrowing entity or a debt issue. In evaluating the firm, credit analysts thoroughly review both public sources of information and relevant private information provided by managers. Particularly, after the enactment of the Regulation Fair Disclosure (FD), credit analysts can have access to confidential information which is not made available to other investment professionals such as equity analysts (Jorion et al. 2005). Therefore, CRAs provide the market with information beyond publicly available sources, contributing to alleviating information asymmetries in the IPO markets (An and Chan 2008; Chan and Lo 2011). Besides their informational role, CRAs also serve an important function as monitors (Arnoud et al. 2006; Bannier and Hirsch 2010; Bonsall et al. 2015). CRAs conduct due diligence on the issuer in the initial rating. They subsequently keep track of the developments that may affect the issuer's risk profiles to adjust their rating accordingly. Reputational concerns and heightened regulatory oversight also strengthen CRAs' incentives to thoroughly monitor the firm (Cheng and Neamtiu 2009). The monitoring by CRAs and the reduced information asymmetry due to the provision of a credit rating make financial reporting misbehaviours more likely to be detected, thereby disincentivising rated IPO firms from opportunistically managing earnings. Moreover, the lower information asymmetries may encourage high-quality rated issuers to signal their future prospects by employing accounting discretion to convey private information to less-informed investors because investors will be more likely to accurately interpret that information. 
Due to the distinct roles of CRAs in the capital markets and the gap in the literature on the influence of CRAs on EM around IPOs, we seek to answer the following research questions: (1) whether rated IPO firms are less likely to engage in EM in the offering year, and (2) whether rated IPO firms employ their accounting and operating discretion to better inform the market. To address these questions, we analyse a sample of U.S. common share IPOs over the period 1991-2011. In order to establish a complete view of EM, we investigate two EM methods: (1) accrual-based EM, which involves exploiting the accounting discretion over the recognition of accruals, and (2) real EM, which entails altering the timing or structuring of real economic activities. Moreover, we account for the selfselection bias, which occurs due to the firm's choice to obtain a credit rating, and the endogeneity problem, which happens due to the potential correlation between EM determinants and factors influencing the firm's decision to solicit a credit rating. We employ alternative econometric techniques to address the endogenous selection issue including Heckman's (1979) two-step treatment effect model, the maximum likelihood treatment effect model, and the instrumental variable model.

We find that rating existence is negatively associated with income-enhancing accrual-based and real EM in the offering year. Credit rating levels, however, do not appear to explain the variation in EM around IPOs. Controlling for the interaction effects between CRAs and venture capitalists, toptier underwriters and big six auditors, we document the impact of CRAs on reducing EM remains, but less pronounced, in the presence of these financial intermediaries. Particularly, the participation of a prestigious underwriter is crucial for a CRA to significantly exert its influence on real EM. Having a reputable auditor also enables CRAs to effectively restrain both accrual-based and real EM by IPO issuers. Furthermore, rating existence influences income-increasing EM in the offering year and also affects managers' intention of exercising their accounting and operating discretion to report higher earnings. We reveal that for unrated firms, at-issue income-increasing EM is unrelated to subsequent earnings and negatively linked to long-run stock performance following the offering. However, for rated firms, at-issue income-increasing EM is positively related to future accounting performance and not associated with post-issue long-run stock performance. The evidence suggests that unrated issuers tend to manage earnings upward to mislead investors, while rated issuers are more likely to employ discretion in accounting and operating decisions to better inform the market. It also supports the role of a credit rating in mitigating the information asymmetry around IPOs. Lower information asymmetry alleviates information uncertainty and allows investors to more immediately recognise EM and adjust for it in their stock valuation; therefore, the post-issue long-run stock returns are insignificantly related to at-issue EM.

Our study makes several contributions to the IPO, EM, and credit rating literature. Prior studies document opportunistic accrual-based EM around IPOs (Aharony et al. 1993; Friedlan 1994; Teoh et 
al. 1998a; Teoh et al. 1998b; Roosenbloom and Van De Goot 2003; DuCharme et al. 2004) and highlight the roles of financial intermediaries including auditors, venture capitalists, and investment banks in restraining EM (Morsfield and Tan 2006; Venkataraman et al. 2008; Lee and Masulis 2011; Hochberg 2012; Wongsunwai 2013). Our findings provide new empirical evidence to support the impact of another important intermediary in the capital markets-CRAs on EM around IPOs. Moreover, we examine both accrual-based and real EM to gain more complete insight into EM activities of IPO firms. In addition, Chen et al. (2013) argue that the extent of information uncertainty around IPOs affects issuers' motives to engage in EM. Specifically, high-information-uncertainty firms opportunistically manipulate earnings, while low-information-uncertainty firms manage earnings for informative purposes. Prior research on CRAs in the IPO markets (e.g., An and Chan (2008), Chan and Lo (2011)) suggests that credit ratings convey useful information that can reduce the information asymmetry around IPOs. We present further empirical evidence of the significance of information environment in influencing managerial incentives to manage earnings. Specifically, we show that lower information uncertainty due to the existence of a credit rating allows investors to more correctly interpret managers' messages. Therefore, rated issuers are more motivated to employ accounting and operating discretion to signal firm value. Additionally, our findings are applicable to an international context as the issue of EM is prevalent in international IPOs (e.g., Roosenboom et al. (2003), Ahmad-Zaluki et al. (2011), Alhadab et al. (2014), Kouwenberg and Thontirawong (2015), and Alhadab et al. (2016)) and CRAs are globally recognised as a crucial information intermediary and a gatekeeper of the capital markets. The paper also provides important implications for practitioners and regulators in evaluating the financial reporting quality of firms going public with a credit rating. For sophisticated investors, our results suggest that the presence of a credit rating can signal higher-quality financial reporting in terms of lower opportunistic EM around IPOs.

The rest of the paper is organised as follows. Section 2 discusses related literature and hypothesis development. Section 3 describes our sample and methodology. Section 4 explains empirical models of the impact of credit ratings on EM and the association between at-issue EM and post-issue accounting and stock performance. Section 5 presents empirical results. Section 6 provides robustness checks for our findings. Finally, Section 7 concludes the paper.

\section{LITERATURE REVIEW AND HYPOTHESES}

\subsection{Earnings management around IPOs}

The theoretical underpinning of our study is agency theory. An important feature of this theory is that it views the firm as a nexus of contracting relationships such as those between executives and 
stakeholders. It is largely concerned with the principal-agent problem due to conflicts of interest between the principal (e.g., shareholders) and the agent (e.g., company executives) that arise in the presence of information asymmetry between the two parties (Jensen and Meckling 1976). The information asymmetry mainly involves the issues of adverse selection and moral hazard. An adverse selection problem occurs when managers have access to private information relevant to decision making. On the other hand, a moral hazard problem happens when managers make decisions that are not aligned with shareholders' interests, yet the latter are unable to observe these actions. Managers' EM choices can be driven by information asymmetries (Dye 1988; Trueman and Titman 1988). When information asymmetries are present, accounting choices can serve as a channel through which insiders can effectively convey information about the magnitude, timing, and risk of future cash flows to lessinformed outsiders; however, compensation, reputation, or other self-interested incentives may induce managers to take advantage of the information disparity to inflate earnings to influence stock prices (Fields et al. 2001).

High information asymmetries are inherent in the IPO markets. When a firm goes public, it discloses its financial information for the first time on the prospectus, which includes financial statements for up to the most recent three years. Public sources of information about private firms are limited. Therefore, much private and valuable information about a new issuer prior to the offering is in the possession of its managers, preventing external investors from thoroughly understanding the firm (Cheung and Krinsky 1994; Barzel et al. 2006; Balatbat 2006). This information disparity between investors and issuers and the lack of reliable independent information sources make it difficult for investors to evaluate the appropriateness of reported accounting figures in reflecting the firm's future performance. Thus, self-interested managers have strong incentives to opportunistically manipulate reported earnings at the time of the IPO to inflate stock prices. In the immediate post-IPO period, the lock-up restriction for the managerial sale of shares, earnings projections, and risks of future lawsuits due to an abnormal drop in stock prices are argued to induce managers to continue to manage earnings upward to maintain high stock prices at the end of the IPO year (Teoh et al. 1998b).

Research on EM around IPOs mainly analyses managers' use of accruals in the period of taking their firms public and finds evidence of income-increasing accrual-based EM around the IPOs (Aharony et al. 1993; Friedlan 1994; Teoh et al. 1998b; DuCharme 2001; DuCharme et al. 2004; Marquardt and Wiedman 2004; Morsfield and Tan 2006; Lee and Masulis 2011)². International studies

\footnotetext{
${ }^{2}$ Ball and Shivakumar (2008) provide a contrary finding. They argue that IPOs attract the attention of regulators and various parties such as auditors, analysts, investors, and the press; thus, issuers are more pressured to provide higher-quality financial reports. Examining a sample of UK firms whose financial statements filed as private firms are comparable to those restated and presented in the
} 
also confirm the aggressive use of accruals by IPO firms in various countries such as the Netherlands (Roosenboom et al. 2003), the United Kingdom (Alhadab et al. 2014; Alhadab et al. 2016), and Asian countries (Ahmad-Zaluki et al. 2011; Kouwenberg and Thontirawong 2015). Despite the extensive research on accrual-based EM around IPOs, evidence on real EM by IPO issuers is less documented. Darrough and Rangan (2005) argue that IPO firms upwardly manage earnings in the issue year by reducing research and development (R\&D) expenses. Cohen and Zarowin (2010) find the evidence of real EM around seasoned equity offerings (SEOs) and document a greater decrease in operating performance due to real EM than due to accrual-based EM in the post-SEO period. Alhadab et al. (2014) report that UK IPO firms engage in both accrual-based and real EM during the offering year in order to overstate earnings. The levels of accrual-based and sales-based EM are higher among IPO firms on the lightly regulated UK Alternative Investment Market than among those on the more heavily regulated UK Main Market (Alhadab et al. 2016).

\subsection{Credit ratings and earnings management around IPOs}

We hypothesise that CRAs can influence EM around IPOs by alleviating the agency problem via two mechanisms: information dissemination and monitoring.

\section{Informational role of credit rating agencies}

CRAs provide the market with their independent assessment of the firm's creditworthiness based on publicly disclosed information in securities filings and relevant private information gathered in the process of due diligence. They assess the likelihood that an issuer will default on its financial obligations by reviewing both financial and non-financial factors such as macroeconomics environment, market conditions, competitive trends, corporate governance, growth prospects, operations and risk management, business plan, and financial position statements. Credit analysts also conduct in-depth interviews and discussions with company managers to obtain additional information and clarification about management policies, current positions, and future plans that may influence the rating. Research on the informational content of rating announcements (e.g., Holthausen and Leftwich (1986), Hand et al. (1992), Dichev and Piotroski (2001)) shows that rating changes significantly influence stock prices, suggesting that CRAs provide valuable information to market participants. Particularly, in 2000, the Securities and Exchange Commission (SEC) enacted the Regulation FD,

IPO prospectuses, they document that IPO firms tend to report more conservatively in response to increasing demand for higher-quality financial reporting by capital market participants. Nevertheless, Lo (2008) argues that sophisticated managers are more likely to provide non-comparable reports to make their earnings manipulation less detectable; therefore, the restrictive sample selection by Ball and Shivakumar (2008) may exclude firms that engage in EM, and the conclusion of no income-enhancing EM by IPO firms may not hold. 
which prohibits publicly traded companies from selectively disclosing private material information to their preferred investment professionals. As CRAs are excluded from the Regulation FD, managers can provide credit analysts with relevant private information about the firm. Therefore, credit ratings convey additional information to the market beyond what is publicly disclosed, contributing to bridging the information gap between issuers and investors. Jorion et al. (2005) show that the informational impact of credit ratings strengthened significantly after the implementation of the Regulation FD. Prior studies also document the role of credit ratings in reducing the information asymmetry problem in the IPO markets (e.g., An and Chan (2008), Chan and Lo (2011)).

\section{Monitoring role of credit rating agencies}

The economic role of CRAs goes beyond mitigating information asymmetries. CRAs are widely considered to be important gatekeepers of the capital markets. Employing their expertise, established methodologies, and access to a wide pool of both public and private information, they provide the market with their assessment of the issuer's creditworthiness. Through the initial investigation, CRAs exert monitoring impacts on the issuer (Bonsall et al. 2015). CRAs' monitoring function is also apparent in their surveillance procedure. After the initial rating, credit analysts maintain periodic contact with the issuer's management to track developments that may affect the issuer's credit risk profiles. As a result of the surveillance analysis, CRAs may adjust the credit rating to reflect timely changes in their opinion of the issuer's creditworthiness. Bannier and Hirsch (2010) argue that CRAs appear to have fulfilled an active monitoring role through their rating review procedures.

CRAs' incentives to monitor are strengthened by their reputational concerns. The credit rating market is concentrated with a limited number of competitors. Thus, the survival and future profitability of CRAs is largely dependent on their reputation, which is directly affected by the performance of the issuer after the rating. To maintain and improve their established reputation, it is crucial for CRAs to closely follow the issuer to assign timely and accurate ratings.

There is a prevalent concern that CRAs' monitoring may be weakened by the conflict of interests inherent in the issuer-pay model (i.e., the issuer pays the CRA for the rating). CRAs' independence may also be compromised when the agency engages in other ancillary business services with the issuer besides the rating. Furthermore, in the past decade, CRAs have faced widespread criticism for their lack of rating timeliness in predicting prominent bankruptcies such as Enron in 2001, WorldCom in 2002, Parmalat in 2003, and the subprime mortgage crisis in 2007-2008. In the aftermath of the financial crisis, CRAs have come under increased scrutiny. Several regulatory reforms have been implemented to enhance the regulation of CRAs, such as the Credit Rating Agency Reform Act of 2006 and the Dodd-Frank Wall Street Reform and Consumer Protection Act of 2010 in the U.S. as well as European Union directives such as the Capital Requirements Directive of 2006. Failing to 
properly monitor the issuer and timely adjust ratings in order to predict a decline in credit quality is costly to CRAs, especially in terms of potential loss of reputation, additional regulatory burdens, and deterioration of future profitability. Cheng and Neamtiu (2009) show that CRAs improve their credit analysis when their market power is threatened by increased regulatory oversight and reputational concerns.

Another relevant issue regards the monitoring of CRAs over the financial reporting process. Rating agencies rely largely on public and private information voluntarily provided by management; hence, the accuracy of their assessment depends considerably on complete and honest information disclosure. In evaluating the issuer, credit analysts use a substantial amount of information from financial statements; therefore, a crucial part of the rating analysis entails the assessment of the quality of reported accounting numbers (Jorion et al. 2009). Although CRAs count on the verification service of auditors and do not repeat their auditing work, following the aftermath of the Internet bubble period, CRAs recruit trained accountants to perform forensic accounting analysis and assist credit analysts in interpreting financial statements (Coffee 2006). Jorion et al. (2009) document that CRAs rationally employ stricter rating criteria upon firms that engage in aggressive EM and adjust their ratings downward to appropriately reflect the firms' true underlying economics.

Overall, the reduced information asymmetry due to the provision of credit ratings and the monitoring by CRAs will make it more likely to discover financial reporting misbehaviours. IPO firms will face severe consequences such as reputation loss, high costs of capital, and litigation risks if they are found to engage in accounting manipulation. Therefore, we expect that managers of rated IPO firms will have weaker incentives to manipulate earnings to influence stock prices. Based upon existing empirical evidence, we examine both accrual-based and real EM by IPO issuers in the offering year and predict that rated IPO firms are less likely to engage in both accrual-based and real EM to overstate earnings. Our first hypothesis is:

H1: Rated IPO firms are less likely to engage in income-increasing EM (accrual-based EM and real EM) than unrated IPO firms in the offering year.

\subsection{At-issue earnings management and post-issue performance of rated IPO firms}

Two opposing streams of literature have emerged regarding the managerial intent in managing earnings around IPOs. One stream supports the view that IPO is an opportunity for initial investors to cash their stock. Therefore, opportunistic managers have a motive to overstate earnings to maximise stock prices. Various studies support this view of managerial opportunism around IPOs (e.g., Aharony et al. (1993), Friedlan (1994), Teoh et al. (1998a), Teoh et al. (1998b), DuCharme et al. (2004), Morsfield and Tan (2006), Lee and Masulis (2011), Thomadakis et al (2016)). The other stream views 
IPO as an external financing occasion; therefore, opportunistically managed earnings are undesirable as managed accruals will be reversed in subsequent periods and will consequently hurt post-IPO stock performance. In order to improve price efficiency and reduce the cost of capital, managers will seek to signal firm value to external investors. EM, in this view, is a means by which managers communicate private information about the firm's future prospects to the market (Watts and Zimmerman 1978; Healy and Palepu 1993; Guay et al. 1996; Subramanyam 1996; Fields et al. 2001; Kallunki and Martikainen 2003; Louis and Robinson 2005; Herbohn et al. 2010).

The extent of information uncertainty may influence managerial intent in managing earnings. In the presence of high information uncertainty, self-interested managers have stronger incentives to opportunistically manipulate earnings because their financial reporting misbehaviours are less likely to be detected (Dye 1988; Trueman and Titman 1988; Healy and Wahlen 1999; Lo 2008). Meanwhile, managers whose incentives are to enhance price efficiency and lower the cost of capital may hesitate to voluntarily disclose private information as investors are less likely to correctly interpret that information (Dutta and Trueman 2002; Fishman and Hagerty 2003; Suijs 2007; Chen et al. 2013). However, in less-uncertain environments, stronger detection risks may keep self-interested managers from manipulating earnings. In addition, managers of high-quality firms can more effectively exercise their accounting discretion to convey inside information to the market because investors can more accurately realise and incorporate the information into their valuation. Chen et al. (2013) examine EM around IPOs operating in the environments of different levels of information uncertainty and find that while high-information-uncertainty firms manipulate earnings opportunistically, low-informationuncertainty firms manage earnings for informative purposes. Along these lines, we expect that lower information uncertainty around IPOs due to the provision of a credit rating before the offering will also influence managerial incentives in undertaking EM. Managers of rated firms will utilise their accounting choices to mitigate the information asymmetry problem and signal the firm's future prospects instead of opportunistically manipulating earnings for short-term self-interests. If managers of rated firms draw on their inside information and exercise their accounting discretion to better inform the market about the firm's future earnings, the extent of income-increasing EM in the offering year will be positively related to subsequent accounting performance. Our second hypothesis is:

H2: At-issue income-increasing EM is positively related to post-issue accounting performance for rated IPO firms.

Extant literature (e.g., Teoh et al. (1998a), Teoh et al. (1998b), and Morsfield and Tan (2006)) documents a negative association between at-issue EM and post-issue long-run stock returns, 
suggesting that managers opportunistically manage earnings to achieve higher offer prices while investors are unable to immediately recognise this behaviour. If managers manipulate earnings upward to inflate stock prices, in subsequent years, the reversal of accruals will drive down future earnings. High stock prices reflect investors' optimistic expectations of the firm's future profitability. Yet, if future earnings do not meet investors' earlier expectations, they will adjust their evaluation of the firm downward. Therefore, IPO firms that opportunistically manage earnings upward in the offering year will exhibit poorer long-run stock performance in the post-issue periods. However, Fields (2001) suggests that positive EM can be intended to convey inside information to external investors so that the stock price can be fairly evaluated. Fan (2007) argues that high-quality IPO firms can use positive EM to a certain degree as a signaling device in order to separate themselves from low-quality firms. The author also documents that investors can accurately interpret the effect of EM when estimating the firm's fundamental value. Chan and Lo (2011) find that rated IPO firms experience more immediate price correction and do not exhibit abnormal long-term stock performance. Their findings indicate that the provision of a credit rating before the new issue lowers information asymmetries and enables investors to correctly estimate the firm's fair market value. As rated IPO firms tend to employ accounting choices to communicate private information to the market, we predict that the lower information uncertainty around rated IPO firms will allow the market to infer EM and correctly adjust for it in valuing the firm. Therefore, the post-issue long-run abnormal stock returns are expected to have no association with the at-issue income-increasing EM. This leads us to our third hypothesis:

H3: At-issue income-increasing EM is not related to post-issue long-run stock performance for rated IPO firms.

\section{SAMPLE AND METHODOLOGY}

\subsection{Sample description}

We construct a sample of U.S. common share IPOs during the period January 1, 1991, to December 31, 2011, from the Securities Data Corporation (SDC) New Issues database ${ }^{3}$. Following IPO literature, we exclude IPOs with an offer price below \$5 per share, unit offerings, limited partnerships, leveraged buyouts (LBOs), rights issues, American depositary receipts (ADRs), closedend funds, real estate investment trusts (REITs), financial institutions, spin-offs, and privatisations.

\footnotetext{
${ }^{3}$ Compustat covers credit rating data from 1985. However, the statement of cash flow data is available for all firms in Compustat from 1988, and we require past-year data to measure earnings management proxies. Thus, our IPO sample period starts from 1991. Moreover, we collect financial information and stock returns for three years following the issue to analyse the post-issue accounting and stock performance.
} 
We then match this sample with the Compustat database where we obtain accounting information, and with the Centre for Research in Security Prices (CRSP) from which we gather stock returns. Credit ratings are collected from Compustat and represent Standard \& Poor's (S\&P) long-term domestic issuer credit ratings. After imposing the aforementioned criteria, we arrive at a final sample of 2,602 IPO firms.

Table 1 presents the distribution of our sample by year, industry, and credit rating level. We observe a larger flow of IPOs in the 1990s, which is consistent with the recovery and expansion period of the U.S. economy after the 1990 recession. The early 2000s recession caused a downturn in the stock market. Subsequently, the overall IPO activity showed some improvement before declining again due to the financial crisis of 2007-2008. Our sample covers 57 industries identified by the two-digit Standard Industrial Classification (SIC) code. Nearly half of the firms are concentrated in computer and high-technology industries (SIC codes 35, 36, 38, and 73). Rated issuers, however, are more strongly presented in manufacturing, transportation and public utilities, and wholesale and retail trade industries. Our overall sample has 153 IPOs with a credit rating one month prior to the stock issuance. The highest rating level is AAA and the lowest is $\mathrm{CCC}+$. Approximately $2 \%$ of the issuers are in the A rating category and $4 \%$ receive investment-grade credit ratings. Nearly half of the firms obtain the rating of $\mathrm{B}+$. The credit ratings of IPO firms are clustered in the rating categories of $\mathrm{BB}-, \mathrm{B}+$, and $\mathrm{B}$. The ratings distribution is consistent with recent research on credit ratings of IPO firms (e.g., An and Chan (2008)).

[Please insert Table 1 about here]

Table 2 reports descriptive statistics for the overall sample and the sub-samples of IPOs with and without a credit rating. Regarding firm characteristics, a typical IPO firm operates for 16 years and has a market value of US $\$ 446$ million, a leverage ratio of 0.73 , a ratio of capital expenditures to total assets of 0.41 , and an industry-adjusted return on assets (ROA) of -0.17. The mean proportion of firms reporting loss in the fiscal year prior to the offering is $37 \%$. In general, $36 \%$ of IPOs are underwritten by reputable investment banks, $92 \%$ are audited by big six accounting firms, and $51 \%$ are venturebacked. Firm-specific characteristics also appear to differ between rated and unrated IPOs. The mean differences are strongly statistically significant for all firm characteristics except for capital expenditures. Rated firms, on average, are older (37 years of age), larger (market value of US\$1,252 million), more leveraged (leverage ratio of 96\%), and more profitable (8\% report losses). Moreover, rated IPOs are more likely to be taken public by prestigious underwriters (68\% of firms) and audited by big six auditors (96\% of firms), but are less likely to seek venture capital backing (18\% of firms). 
Our results are consistent with prior literature. For instance, Denis and Mihov (2003) and Faulkender and Petersen (2006) also report that large, mature, profitable, and highly leveraged companies are more likely to issue public debts and obtain credit ratings.

[Please insert Table 2 about here]

With respect to EM proxies, we rely on the median for statistical inference as the median is less likely than the mean to be affected by extreme observations. For the whole sample of IPO firms, the median abnormal accruals (0.02) are significantly positive. In line with previous studies, we find evidence that IPO firms engage in accrual-based EM around IPOs to report higher earnings. The median abnormal cash flow from operations (0.03) is also significantly positive, implying that IPO firms tend to manipulate sales to bias earnings upward. Meanwhile, the median values of abnormal production costs (-0.08), abnormal discretionary expenses (-0.25), and the two aggregate real EM proxies REM1 (-0.30) and REM2 (-0.21) are all significantly negative. The preliminary evidence that IPO firms engage in income-increasing real EM through sales manipulation but not through overproduction and discretionary expenses is intuitive. First, sales manipulation is less likely to be discovered given that newly listed firms are expected to have growth in sales. Moreover, increasing sales while at the same time reducing discretionary expenses such as advertising and selling, general and administrative (SG\&A) expenses is not only difficult to accomplish but also likely to attract attention and scrutiny from auditors, regulators, and investors. In addition, production cost manipulation can only be fully employed by manufacturing firms (Roychowdhury 2006). Our sample consists of a small proportion of manufacturing firms; thus, the inability to fully exploit productionbased real EM may deter IPO firms from undertaking this method to manage earnings upward.

Similarly, unrated firms have significantly positive median abnormal accruals (0.03) and abnormal cash flow from operations (0.03), yet have significantly negative median abnormal production costs (-0.09), abnormal discretionary expenses (-0.29), REM1 (-0.40), and REM2 (-0.24). This indicates that unrated firms tend to engage in income-increasing EM through accruals and sales manipulation, yet they make conservative operating decisions related to production and discretionary expenses. On the other hand, for rated firms, all EM measures apart from REM1 are not significantly different from zero. This suggests that rated issuers do not appear to engage in EM by manipulating accruals, sales, production, or discretionary expenses. The tests of the differences in the medians of EM proxies between the two samples show significant results and suggest that rated issuers are less likely to engage in accrual-based and real EM in the listing year than unrated issuers. 
The results so far show an initial insight into the relation between credit ratings and EM. Overall, unrated firms exhibit income-increasing EM through accruals and sales manipulation; on the other hand, rated firms are not involved in either accrual-based or real EM in the issue year. Comparing the samples of rated and unrated firms, the results reveal that rated IPOs exhibit lower EM through both accruals and real activities than their unrated counterparts. In order to establish more concrete evidence, in the next section we provide multivariate analyses controlling for several determinants of EM.

\subsection{Methodology}

We employ the modified Jones (1991) model described in Dechow et al. (1995) to estimate abnormal accruals as a proxy for accrual-based EM. ${ }^{4}$ In order to mitigate the correlation between estimated abnormal accruals and firm performance, we follow the performance matching procedure of Kothari et al. (2005). The abnormal accruals of IPO firms are adjusted for those of performancematched non-IPO peers. The performance matching is based on year, industry, and ROA. The methodology of measuring accrual-based EM is described in more detail in Appendix B.

For real EM, we follow Roychowdhury (2006) to analyse three real EM tools that managers may employ to bias earnings: sales manipulation, overproduction, and discretionary expenses reduction. Temporarily boosting sales through price discounts or lenient credit terms will lead to unusually lower cash flow from operations. Overproduction to lower cost of goods sold and improve margins will result in unusually higher production costs. Cutting advertising, R\&D, and SG\&A expenses to increase earnings will cause unusually lower discretionary expenses. Therefore, firms that engage in these real EM activities to overstate earnings tend to have lower abnormal cash flow from operations, higher abnormal production costs, and lower abnormal discretionary expenses. The normal levels of cash flow from operations, production costs, and discretionary expenses are estimated based on models developed by Dechow et al. (1998). The abnormal levels are the actual amount deviated from the estimated normal levels. We also adjust the real EM measures of IPO firms for those of performancematched non-IPO firms. In order for our real EM measures to have a similar interpretation to our accrual-based EM measure, we multiply the computed measures of abnormal cash flow from operations and abnormal discretionary expenses by minus one so that higher values indicate higher real EM. We also compute two aggregate measures to account for the total effect of real EM: REMI

\footnotetext{
${ }^{4}$ As EM is unobservable and its measurement is largely dependent on the model used, for robustness check, we implement another accruals model by Dechow and Dichev (2002) to estimate abnormal accruals. Details of this methodology are explained in Appendix B. Our results (untabulated) are consistent with those obtained using the performance-matched modified Jones (1991) model.
} 
represents the combined effects of earnings manipulation through production costs and discretionary expenses, while REM2 represents the combined effects of earnings manipulation through sales and discretionary expenses. Similarly, higher values suggest more income-enhancing real EM. Details of our real EM estimation methodology are presented in Appendix B.

\section{EMPIRICAL MODELS}

\subsection{Credit ratings and earnings management around IPOs}

We estimate the following regression model to examine the association between credit ratings and EM around IPOs:

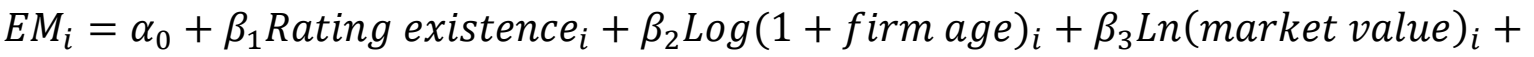

$$
\begin{aligned}
& \beta_{4} \text { Leverage }_{i}+\beta_{5} \text { Loss }_{i}+\beta_{6} \text { Highly ranked underwriter }_{i}+\beta_{7}{\text { Big } 6 \text { auditor }_{i}+}+ \\
& \beta_{8} \text { Venture capitalist }_{i}+\beta_{9}{\text { Industry adjusted } R O A_{i}+\beta_{10} \text { CAPEX }}_{i}+\sum_{1991}^{2011} \beta \text { Year }+\varepsilon_{i}
\end{aligned}
$$

where $E M_{i}$ is the positive value of an EM measure including abnormal accruals, abnormal cash flow from operations, abnormal production costs, abnormal discretionary expenses, REM1, and REM2 in the fiscal year of the offering. Rating existence ${ }_{i}$ is our main variable of interest that equals to one if the firm has a credit rating, and zero otherwise. We include the control variables in Equation (1) as suggested by prior EM literature. Definitions of all variables are presented in Appendix A.

We account for several firm characteristics that may determine the level of EM undertaken in the issue year. First of all, we include $\log (1+$ firm age $)$ to control for firm age. Firms with long-standing establishment tend to develop more solid management and accounting systems. On the other hand, younger companies often exhibit poor financial performance and less stable earnings; thus, they have more incentives to manipulate earnings. We also control for firm size by including $\ln$ (market value). Larger firms have greater operation scales and more complex financial structures, which make it easier for managers to exploit accounting policies and operating decisions to manage earnings. However, they face closer scrutiny from regulators and capital market players, which may discourage managers from becoming involved in dishonest activities (Lee and Masulis 2011).

Moreover, DeFond and Jiambalvo (1994) and Franz et al. (2014) suggest that firms with high leverage are more likely to manipulate accruals to avoid debt covenant violation. Hence, we include leverage to control for the possibility that highly leveraged firms tend to overstate earnings. Additionally, Burgstahler and Dichev (1997) and Degeorge et al. (1999) posit that firms engage in EM to exceed the positive profit threshold. Thus, we include loss to account for the probability of higher income-increasing EM among firms operating at a loss. 
Furthermore, prior studies document that financial intermediaries participating in the IPO process can contribute to curtailing EM. Lee and Masulis (2011) report a negative association between underwriter reputation and EM by IPO issuers. Therefore, we include highly ranked underwriter to control for this effect of top-tier underwriters. We also add big6 auditor to capture the capability of experienced auditing firms in detecting misrepresentations in financial reports as suggested by Becker et al. (1998), Krishnan (2003), and Gul et al. (2009). Moreover, we include venture capitalist as venture capitalists can play a monitoring role and restrain EM around IPOs (Morsfield and Tan 2006; Lee and Masulis 2011; Hochberg 2012; Wongsunwai 2013).

In addition, investors face higher uncertainty in evaluating high-growth firms as the firm value is substantially derived from future uncertain growth opportunities. Therefore, managers of these firms have better chances to mislead investors through earnings manipulation (Fan 2007). We use the average capital expenditures in the offering year and one year after scaled by total assets at the beginning of the offering year, CAPEX, as a proxy for growth. We also account for firm performance by including industry-adjusted ROA in the regression.

Our variable of interest is rating existence, which indicates whether the firm has a credit rating before the offering. The provision of a credit rating may not be random across firms as they can choose to be rated. An issuer's decision to acquire a credit rating may depend on various firm-specific characteristics which make the existence of a rating beneficial to the firm. For instance, Faulkender and Petersen (2006) claim that firms that are larger, have been operating for a longer time, and have greater profitability, higher leverage, and more tangible assets tend to issue public debts and obtain credit ratings. Firm characteristics which induce the firm to issue debts and have a credit rating may also determine the firm's choice to undertake EM. Thus, the potential issues of selection bias and endogeneity may result in a biased coefficient estimate of rating existence.

To address this issue, we follow related literature (Faulkender and Petersen 2006; An and Chan 2008; Karampatsas et al. 2014) to account for the endogenous selection issue by employing several econometric models including Heckman's (1979) two-step treatment-effect model, the maximum likelihood estimation (MLE) treatment-effect model, and the two-stage least squares (2SLS) instrumental variable (IV) model. These econometric approaches require the estimation of a selection model that accounts for factors influencing the firm's choice to acquire a credit rating. It is important to select variables which are correlated with the probability of having a rating in the selection model but do not directly explain EM in the outcome model. Therefore, instead of including firm characteristics in the selection model, we account for industry characteristics and exclude industry fixed effects in our regressions to avoid weak instrument biases and invalid inferences. Faulkender and Petersen (2006) argue that firms operating in an industry with a large proportion of public debt issuers 
tend to have lower information costs because the bond market is already familiar with the industry and competitors. Lower information costs also mean that it is more likely for the bank to underwrite a bond issue. Therefore, a firm tend to issue public debts and obtain a credit rating if it operates in an industry with more rated firms. To control for this effect, we create the variable industry fraction, which is calculated as the logarithm of one plus the percentage of firms that have credit ratings in the same three-digit SIC industry as the IPO firm in the fiscal year before the offering. Moreover, Johnson (1997) and Cantillo and Wright (2000) demonstrate that firms in more profitable and less risky industries are more likely to gain access to public debt markets due to their low default probability. Hence, we control for the significance of industry profitability and risks in determining the probability of a firm holding a credit rating. We measure industry profitability as the median ratio of earnings before interest, taxes, depreciation, and amortisation (EBITDA) to total assets of firms in the same three-digit SIC industry as the IPO firm in the fiscal year before the offering. Industry risk is computed as the standard deviation of the industry's profitability.

The Heckman (1979) correction for self-selection bias involves two-step estimation. In the first step, we estimate the selection equation using a probit regression of rating existence on industry fraction, industry profitability, and industry risk. The self-selection correction term, i.e. the inverse Mills ratio, is estimated and added to the outcome Equation (1) and the linear regression is estimated as normal. For MLE treatment effect model, the selection and outcome equations are estimated simultaneously by the maximum likelihood estimation. This method is more efficient than the twostep treatment effect model if the error terms in the selection and outcome equations have a bivariate normal distribution (An and Chan 2008). For 2SLS IV model, in the first stage, we estimate the regression of rating existence on all exogenous variables in the main Equation (1) and the excluded instruments, namely, industry fraction, industry profitability, and industry risk. In the second stage, the main regression is estimated with the endogenous variable rating existence being replaced by the predicted value from the first stage.

\subsection{At-issue earnings management and post-issue performance}

We examine the relation between income-increasing EM in the offering year and subsequent accounting performance in order to evaluate whether managers of IPO firms exercise their accounting discretion to mislead investors or to better inform the market. Subramanyam (1996) documents that the positive association between accounting discretion and subsequent operating cash flows indicates the informative role of EM in signaling future performance. Using cash flow from operations (CFO) as a measure of future performance can avoid the correlation between current accruals and future earnings due to accrual reversals; however, CFO lacks timeliness as a performance measure (Dechow 
1994; Bowen et al. 2008). Another widely used performance measure is return on assets (ROA), which is a direct measure of future profitability. ROA is less likely to have the timeliness issue, yet ROA tends to be influenced by accrual reversals as the accruals employed in the past may be correlated with future accruals and ultimately with ROA (Bowen et al. 2008). Each performance measure has its own strengths and weaknesses. In order to provide more robust findings, we employ both measures of accounting performance in our analysis.

We estimate the following regressions to examine the relation between at-issue incomeincreasing EM and accounting performance in the subsequent year:

$$
\begin{gathered}
C F O_{i, t=1}=\alpha_{0}+\beta_{1} E M_{i, t=0}+\beta_{2} E M_{i, t=0} * \text { Rating existence } e_{i, t=0}+\beta_{3} C F O_{i, t=0}+ \\
\beta_{4} C A P E X_{i, t=0}+\sum \beta \text { Industry }+\sum_{1991}^{2011} \beta \text { Year }+\varepsilon_{i} \\
R O A_{i, t=1}=\alpha_{0}+\beta_{1} E M_{i, t=0}+\beta_{2} E M_{i, t=0} * \text { Rating existence } e_{i, t=0}+\beta_{3} R O A_{i, t=0} \\
+\beta_{4} C A P E X_{i, t=0}+\sum \beta \text { Industry }+\sum_{1991}^{2011} \beta \text { Year }+\varepsilon_{i}
\end{gathered}
$$

where $C F O_{i, t=1}$ is cash flow from operations scaled by lagged total assets in the fiscal year following the IPO; $R O A_{i, t=1}$ is net income scaled by lagged total assets in the fiscal year following the IPO; $E M_{i, t=0}$ is the positive value of an EM measure including abnormal accruals, abnormal cash flow from operations, abnormal production costs, abnormal discretionary expenses, REM1, and REM2 in the offering year; $E M_{i, t=0} *$ Rating existence $e_{i, t=0}$ is an interaction term between at-issue $E M$ and the presence of a credit rating. We add current performance measures $\left(C F O_{i, t=0}, R O A_{i, t=0}\right)$ to control for potential mean-reversion in the measures of accounting performance (Barber and Lyon 1996; Bowen et al. 2008). We also include CAPEX to account for the effect of the investment of proceeds on postissue performance (Teoh et al. 1998b).

If managers manipulate either accruals or operating activities to overstate earnings for opportunistic purposes to mislead investors, the earnings will not be sustainable and at-issue incomeincreasing EM will not reflect the firm's future prospects. On the other hand, if managers engage in EM with the aim of communicating private information to the market, at-issue EM will be related to the firm's future performance. We expect that managers of rated IPO firms tend to engage in incomeenhancing EM to signal their value; therefore, the sum of the estimated coefficients $\left(\beta_{1}+\beta_{2}\right)$ will be significantly positive. 
To examine the impact of at-issue income-increasing EM on the post-issue long-run stock performance, we regress post-issue three-year buy-and-hold abnormal returns (BHARs) on at-issue EM. The regression is estimated as follows:

$$
\begin{aligned}
& \text { BHAR }_{i}=\alpha_{0}+\beta_{1} E M_{i}+\beta_{2} E M_{i} * \text { Rating existence }_{i}+\beta_{3} \text { Underpricing }_{i}+
\end{aligned}
$$

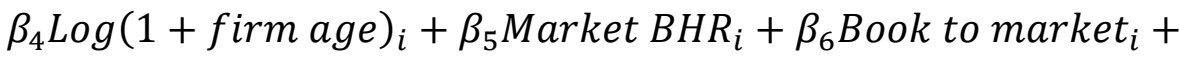

$$
\begin{aligned}
& \beta_{7} \operatorname{Ln}(\text { market value })_{i}+\beta_{8} R O A_{i}+\beta_{9} \text { Highly ranked underwriter }{ }_{i}+ \\
& \beta_{10} \text { Big6 }_{\text {auditor }}+\beta_{11} \text { High tech industry }{ }_{i}+\sum_{1991}^{2011} \beta \text { Year }+\varepsilon_{i}
\end{aligned}
$$

where $B H A R_{i}$ is the firm's post-issue three-year buy-and-hold abnormal return calculated starting from the day after the annual financial report date in the offering year to the earlier of the three-year anniversary date or the delisting date; $E M_{i}$ is the positive value of an EM measure (abnormal accruals, abnormal cash flow from operations, abnormal production costs, abnormal discretionary expenses, $R E M 1$, or REM2) in the offering year. We include control variables in Equation (3) as suggested by prior studies (Ritter 1991; Teoh et al. 1998a; Chen et al. 2013). Definitions of these variables are presented in Appendix A. The existence of a credit rating reduces the information uncertainty, creating incentives for managers of rated firms to release private information to signal firm quality and also allowing investors to properly interpret this information and incorporate it into their firm valuation. Therefore, price adjustment will occur in the short run, leaving insignificant long-run abnormal stock returns. Therefore, we expect that at-issue EM of rated firms will be unrelated to long-run stock performance, and the sum of the estimated coefficients $\left(\beta_{1}+\beta_{2}\right)$ will be insignificantly different from zero.

As an additional check, we examine long-run stock performance using the calendar-time portfolio approach ${ }^{5}$ : the Fama and French (1993) three-factor model, and the Carhart (1997) fourfactor model. The regression model estimated based on the Fama and French (1993) three-factor model is as follows:

$$
\text { POSEM }_{p t}-N E G E M_{p t}=\alpha_{p}+\beta_{m} M K T_{t}+\beta_{s} S M B_{t}+\beta_{h} H M L_{t}+\varepsilon_{t}
$$

where $P O S E M_{p t}-N E G E M_{p t}$ is the return from taking a long position in a portfolio of IPO firms that manage earnings upward and a short position in a portfolio of IPO firms that manage earnings downward for each calendar month in the sample period. $M K T_{t}$ is the excess monthly return on the

\footnotetext{
${ }^{5}$ Buy-and-hold returns are representative of investors' investment experience; therefore, they are commonly used to examine long-run stock performance. However, Fama (1998) points out several concerns regarding the use of buy-and-hold returns in long-run performance studies including the exaggeration of short-term estimation errors through compounding, the skewness in the distribution of buy-and-hold returns, and the cross-correlation problems caused by time-period overlap. Fama (1998) also advocates the use of the calendar-time approach to examine the long-run performance as the approach can account for the clustering of events and crosscorrelation problems and better approximate the normal distribution, hence, produce more reliable statistical inferences.
} 
value-weighted CRSP index for each calendar month in the sample period. $S M B_{t}$ is the difference in the returns of value-weighted portfolios of small and large stocks for each calendar month in the sample period. $H M L_{t}$ is the difference in the returns of value-weighted portfolios of high book-to-market and low book-to-market stocks for each calendar month in the sample period. The IPO firm's returns are included in the portfolio returns for the period of three years after the IPO fiscal year end. The Carhart four-factor model adds to the Fama and French three-factor model an additional factor to account for one-year momentum price return. The factors for those models are retrieved from Professor Kenneth French's website ${ }^{6}$. The regression is estimated for separate samples of unrated and rated IPO firms. The intercept of the factor model represents the average monthly abnormal return. Following Chen (2013), we use an intercept test to examine the difference in post-IPO stock performance between issuers with aggressive EM and those with conservative EM. In the case that the provision of a credit rating reduces information asymmetry and allows investors to better gauge the managerial intention in EM and adjust accordingly, the future stock returns will be unrelated to EM in the offering year. Therefore, we expect that the intercept of the regression estimated for the sample of rated IPO firms is insignificantly different from zero.

\section{EMPIRICAL RESULTS}

\subsection{Credit ratings and earnings management around IPOs}

Table 3 reports our regression analyses of the association between accrual-based EM and rating existence using the three estimation methods: Heckman's two-step treatment effect model, MLE treatment effect model, and 2SLS IV model.

[Please insert Table 3 about here]

The evidence from the three estimation approaches confirms the presence of the endogenous selection problem. The inverse Mills ratio from the Heckman two-step treatment effect model is significant at the 5\% level, suggesting the issue of selection bias. The likelihood ratio test of the correlation between the two error terms of the selection and outcome equations from the MLE treatment effect model provides a strongly significant result. This indicates that unobservable firm characteristics determining the decision to obtain a credit rating also influence EM activities. The

\footnotetext{
${ }^{6}$ http://mba.tuck.dartmouth.edu/pages/faculty/ken.french/data_library.html
} 
Durbin-Wu-Hausman test of endogeneity from the 2SLS IV model also verifies the endogeneity problem.

The coefficients on rating existence are negative and statistically significant at either $1 \%$ or $5 \%$ levels, suggesting that rated firms are less likely to engage in income-increasing EM. The signs of the coefficients on control variables are generally in line with prior literature. We document that IPOs with a longer operating history, lower leverage, less growth, and venture-backing are less likely to manage earnings. Among the three industry characteristic variables in the selection equation, industry fraction is positively associated with rating existence across all specifications. This is similar to the findings of earlier studies that the probability of having a credit rating increases for firms in industries with more rated debt issuers.

Table 4 presents multiple regression analyses of different measures of real activities manipulation on rating existence. The results of the inverse Mills ratio test, the likelihood ratio test, and the Durbin-Wu-Hausman test confirm the endogenous selection problem. Panels A, B, and C report the results of regressions estimated using the three econometric techniques: Heckman two-step treatment effect model, MLE treatment effect model, and 2SLS IV model, respectively.

[Please insert Table 4 about here]

Our results consistently hold for alternative econometric models and different measures of real EM. The coefficients on all individual metrics of real EM-abnormal cash flow from operations, abnormal production costs, abnormal discretionary expenses, and the combined real EM measures REM1 and REM2 - are significantly negative. This supports the conjecture that rated IPOs are less likely to manage earnings through real activities manipulation. The control variables have the expected signs. We document significant lower real EM for IPO firms that are older, more profitable, underwritten by reputable investment banks, venture-backed, and have lower leverage and less growth. Industry fraction is again consistently highly significant across all specifications. Overall, the results support our first hypothesis that rated IPO firms demonstrate less income-enhancing accrual-based and real EM in the issue year than unrated IPO firms.

\subsection{At-issue earnings management and post-issue performance}

We present our results of the analyses of at-issue income-increasing EM and post-issue accounting performance measured by future CFO and ROA in Table 5. Panel A shows the regressions with CFO as a dependent variable. The coefficients on abnormal accruals, abnormal cash flow from operations, abnormal production costs, REM1, and REM2 are insignificant. This suggests that 
managers of unrated IPO firms tend to engage in income-increasing EM in the offering year without the aim of informing the market about the firm's future performance. The coefficients on the interaction term $E M^{*}$ Rating existence are significantly positive at either the $1 \%$ or $5 \%$ level for all EM measures. Moreover, the sums of the estimated coefficients of EM and EM*Rating existence are significantly positive, indicating that the level of income-increasing EM in the issue year is positively related to the subsequent accounting performance for rated issuers.

[Please insert Table 5 about here]

Panel B presents regressions using ROA as a measure of accounting performance. For unrated issuers, future earnings are more likely to worsen with the extent of income-increasing EM in the issue year, while for rated issuers, the extent of income-increasing EM during the IPO year is positively linked to subsequent future earnings. For robustness, we check our results using the industry-adjusted CFO and ROA as well as the average CFO and ROA over the three years after the IPO. We obtain similar evidence (untabulated) suggesting the informative purposes of rated IPO firms in employing their accounting discretion in the offering year. Overall, the findings support our second hypothesis that at-issue income-increasing EM is positively associated with subsequent accounting performance for rated IPO firms. This is consistent with our notion that managers of rated IPO firms exercise their accounting and operating discretion to better inform the market.

We report the analyses of the post-issue long-run stock performance in Table 6. Panel A presents the regressions of post-issue three-year BHARs on at-issue income-increasing EM. The coefficients on abnormal accruals, abnormal cash flow from operations, and abnormal production costs are significantly negative. This suggests that managers of unrated IPO firms generally manipulate earnings through accruals, sales, and production for opportunistic purposes to mislead investors. In a highinformation-asymmetry environment, investors are less likely to recognise managers' manipulation activities; hence, when actual earnings in the future do not meet their expectation, they revise their valuation downward, resulting in negative abnormal stock returns in the post-issue period. The insignificance of the F-tests of $[E M+E M *$ Rating existence $=0]$ across all specifications indicates that for rated IPO firms, post-issue long-run stock performance is generally unrelated to the extent of income-increasing EM in the offering year.

[Please insert Table 6 about here] 
Panel C presents the analyses of the Fama and French three-factor model and the Carhart fourfactor model. The results are consistent for both models. The intercept estimates of the regressions using abnormal accruals and abnormal cash flow from operations to measure EM are negative and significant for the sample of unrated IPOs. This indicates that unrated issuers who aggressively employ accrual-based and sales-based EM underperform those who conservatively undertake these EM tools. However, for the sample of rated IPOs, the intercept estimates are insignificantly different from zero across all specifications apart from the one using abnormal production costs as an EM proxy. Thus, for rated issuers, the difference in post-issue long-run abnormal stock returns is not significant between aggressive and conservative issuers.

The results from the analysis of long-term stock performance using BHARs and factors models support our third hypothesis that post-issue long-run stock performance is unrelated to at-issue incomeincreasing EM for rated issuers. This is consistent with our conjecture that lower information asymmetry due to the provision of a credit rating allows investors to more accurately interpret the information conveyed by managers through EM and incorporate it into their firm valuation, resulting in insignificant long-run abnormal stock returns.

\section{ROBUSTNESS CHECKS}

\subsection{Interaction effects of credit rating agencies and other financial intermediaries}

Auditors, venture capitalists, and investment banks are financial intermediaries that are closely involved in the IPO process. Several studies indicate the constraining effects of these intermediaries on EM by IPO firms. Venkataraman et al. (2008) report that auditors are more conservative in auditing IPO firms' financial reports due to greater litigation exposure in the IPO market. Morsfield and Tan (2006), Hochberg (2012), and Wongsunwai (2013) suggest that the monitoring by venture capitalists inhibits EM by IPO firms. Jo et al. (2007) argue that due to reputational concerns and litigation risks, prestigious underwriters make an effort to constrain EM. Lee and Masulis (2011) also document a negative association between EM and more reputable venture capitalists and investment banks. In the main analysis, we find that CRAs reduce EM by IPO issuers. In this section, we control for the interaction effects of CRAs and major financial intermediaries taking part in the IPO process. Specifically, we examine whether CRAs exert influence on EM decisions by IPO firms which are venture-backed, underwritten by reputable investment banks, or audited by big six accounting firms. We create interaction terms between rating existence and each of the variables venture capitalist, highly ranked underwriter, and big6 auditor. We then run regressions separately for each interaction effect. The results are presented in Table 7. 
[Please insert Table 7 about here]

Panel A reports the results of the regressions of EM on rating existence controlling for the interaction effect between CRAs and venture capitalists. The coefficients on rating existence remain significantly negative, indicating that without the involvement of a venture capitalist, CRAs still significantly reduce EM. The F-tests of [Rating existence + Rating existence*Venture capitalist $]$ give significant negative results in regressions with abnormal accruals, abnormal cash flow from operations, and REM2 as dependent variables. This suggests that when a venture capitalist is present, rated issuers have significantly lower levels of accrual-based EM, sales-based real EM, and the combination of sales and discretionary expense manipulation.

The results presented in Panel B account for the interaction effect between CRAs and top-tier underwriters. The coefficient on rating existence is significantly negative only for the regression with the dependent variable of abnormal accruals. This indicates that without a reputable underwriter, having a CRA is associated with lower accrual-based EM, but not with lower real EM. Moreover, we obtain significant negative results for the F-tests of [Rating existence + Rating existence*Highly ranked underwriter] for specifications using abnormal accruals, abnormal cash flow from operations, abnormal discretionary expenses, and REM2 as EM measures. This shows that among IPO firms having a prestigious underwriter, rated ones have significantly lower EM through accruals, sales, and discretionary expenses.

Panel C illustrates the results of the regressions controlling for the interaction effect between CRAs and big six auditing firms. The presence of a CRA is significantly related to lower accrual-based and real EM only for firms being audited by a big six accounting firm. This implies that the certification of financial statements by an experienced auditing firm is important for a CRA to effectively exert its influence on EM by an IPO firm.

\subsection{Other robustness tests}

The results so far indicate that managers in rated firms are less likely to manipulate either accruals or real activities to distort reported earnings. We further examine whether credit rating levels can explain the extent of EM in the IPO year. We create the variable rating level which takes the value from 1 to 22 , which is equivalent to the lowest rating D to the highest rating AAA. A higher rating corresponds to a higher value. We regress different EM proxies on rating level and other controls for determinants of EM as previously discussed in Section 4.1. The model is similar to Equation (1) with the variable Rating existence being changed to Rating level. The variable Industry fraction in the 
selection equation is replaced by Industry level, which is the median credit rating level of rated firms in the same three-digit SIC industry as the IPO firm. In untabulated results, we do not find significant association between credit rating levels and EM around IPOs. Thus, what matters in influencing EM by IPO firms are the presence of CRAs and the existence of a credit rating, not the rating per se. ${ }^{7}$

In addition, the credit rating sector is highly concentrated with the three largest CRAs (i.e. Standard \& Poor's, Moody's Investors Service, and Fitch Inc.) covering approximately 95\% of the rating business. For robustness, we expand our sample of rated IPOs to include firms obtaining ratings from either of the three CRAs. The data for long-term corporate credit ratings from Moody's Investors Service and Fitch Inc. are extracted from Bloomberg. This increases our sample of rated IPOs to 174 firms with 47 firms having credit ratings from more than one rating agency. The findings (untabulated) also show that rated firms are less likely to engage in accrual-based and real EM.

Furthermore, concerns have been raised regarding the ability of CRAs to give advance warning of financial crises. For example, during the Internet bubble period, S\&P and Moody's assigned investment grade ratings to Enron, WorldCom, and Parmalat just a short period before they went bankrupt $^{8}$. In July 2007, the U.S. market witnessed a mass significant downgrade by CRAs for thousands of residential mortgage-backed securities that were issued a year earlier. Thus, we add additional controls for these turbulent periods, specifically, the dot-com bubble period of 1999-2000 and the financial crisis of 2007-2008. Another important event that may affect our results is the passage of the Sarbanes-Oxley Act (SOX). SOX was passed by the U.S. Congress and enacted in 2002 as a reaction to a series of corporate scandals including those affecting Enron and WorldCom. The bill aims to restore investor confidence in financial reporting and assure the integrity of capital markets. It entails a number of strict regulations to strengthen financial disclosures and protect investors from potential fraudulent accounting practices. Lobo and Zhou (2006) report that SOX requirement for the certification of financial statements by CEOs and CFOs influences managerial accounting discretion towards higher conservatism in financial reporting. Cohen et al. (2008) also document changes in

\footnotetext{
${ }^{7}$ As an additional check, we create an indicator variable that equals to one if the credit rating is investment-grade (BBB-and above) and test whether EM is different among firms with investment-grade credit ratings. We find that credit rating investment grades do not explain the variation in EM by IPO issuers. Moreover, as the majority (96\%) of firms in our sample have non-investment-grade credit ratings ( $\mathrm{BB}+$ and below) and the rating levels cluster in the range of 7 to 12 (equivalent to $\mathrm{B}-$ to $\mathrm{BB}+$ ), we also check our results on the sample of IPO firms whose rating levels range from 7 to 12 and obtain similar results.

${ }^{8}$ During the Internet bubble period, S\&P and Moody's assigned investment-grade ratings to Enron until November 27, 2001—six days before its bankruptcy. Moody’s and S\&P gave WorldCom investment-grade ratings about two months before its bankruptcy. Parmalat also received an investment-grade rating from S\&P until 18 days before its bankruptcy on December 27, 2003 (Coffee 2006).
} 
managerial choices of EM methods towards more real EM after the passage of SOX. Thus, we include a dummy variable indicating IPOs occurring after the passage of SOX. Controlling for the dot-com, crisis, and post-SOX periods, we obtain consistent results (untabulated) with the main analysis.

\section{CONCLUSION}

This study provides new empirical evidence of the impact of credit ratings on accrual-based and real EM around IPOs. We find a negative association between rating existence and income-increasing accrual-based and real EM in the offering year. Rating levels, however, are not significantly related to at-issue EM. This suggests the importance of rating existence and CRAs in restraining EM by IPO issuers. The provision of a credit rating reduces information asymmetry around IPOs, thereby making it more likely for EM to be detected. Moreover, CRAs are highly capable of identifying managers' misbehaviours due to their profound expertise, experience, and access to a large pool of both private and public information. Reputational concerns and litigation risks also strengthen CRAs' incentives to thoroughly monitor issuers and detect their reporting misrepresentations. Thus, the monitoring by CRAs and lower information asymmetry due to the provision of a credit rating disincentivise rated firms from manipulating reported earnings through accrual and real activities. The participation of financial intermediaries engaging in the IPO process including venture capitalists, underwriters and auditors is also important for CRAs to effectively restrain EM. When a venture capitalist is not involved, CRAs still significantly reduce both accrual-based and real EM. However, without a prestigious underwriter, having a CRA is associated with lower accrual-based EM, but not with lower real EM. Particularly, the presence of a reputable auditor is essential for CRAs to significantly exert their influence on both accrual-based and real EM. Our main results are robust when we use ratings data from S\&P, Moody's, and Fitch to determine the existence of a credit rating. The findings also remain consistent when controlling for critical periods that may affect the influence of CRAs on EM including the Internet bubble (1999-2000), the financial crisis (2007-2008), and the post-Sarbanes Oxley Act (2002).

Furthermore, we examine the influence of rating existence on managerial intent to exercise accounting and operating discretion to inflate earnings in the IPO year. For unrated issuers, the at-issue income-increasing EM is not related to future earnings. However, for rated issuers, the incomeincreasing EM in the offering year is positively linked to subsequent accounting performance. In addition, analysing post-issue long-run stock performance, we reveal that at-issue income-increasing EM is negatively related to post-issue long-run stock returns for unrated firms, while the relationship is insignificant for rated firms. The findings suggest that unrated issuers tend to opportunistically 
manage earnings around IPOs and investors are unable to see through this behaviour. On the contrary, rated issuers are more likely to employ their discretion in accounting and operating decisions to convey the firm's future prospects to the market. Overall, our study uncovers the significance of rating existence in explaining the extent of income-increasing EM around IPOs and managers' purposes in utilising their accounting and operating discretion to report higher financial outcomes. 


\section{References}

Aharony, J., C. Lin, and L. Loeb (1993), 'Initial Public Offerings, Accounting Choices and Earnings Management'. Contemporary Accounting Research, Vol 10, No. 1, pp. 61-81.

Ahmad-Zaluki, N. A., K. Campbell, and A. Goodacre. (2011), 'Earnings Management in Malaysian IPOs: The East Asian Crisis, Ownership Control and Post-IPO Performance'. The International Journal of Accounting, Vol 46, No. 2, pp. 111-137.

Alhadab, M., I. Clacher, and K. Keasey (2014), 'Real and Accrual Earnings Management and IPO Failure Risk'. Accounting and Business Research, Vol 45, No. 1, pp. 55-92.

Alhadab, M., I. Clacher, and K. Keasey (2016), 'A Comparative Analysis of Real and Accrual Earnings Management around Initial Public Offerings under Different Regulatory Environments'. Journal of Business Finance \& Accounting:n/a-n/a.

An, H., and K. Chan (2008), 'Credit Ratings and IPO Pricing', Journal of Corporate Finance, Vol 14, No. 5, pp. 584-595.

Arnoud, W. A. B., T. T. Milbourn, and A. Schmeits (2006), 'Credit Ratings as Coordination Mechanisms', The Review of Financial Studies, Vol 19, No. 1, pp. 81-118.

Balatbat, M.C.A (2006), 'Discussion of Explaining the Short- and Long-Term IPO Anomalies in the US by R\&D'. Journal of Business Finance \& Accounting, Vol 33, No. 3-4, pp. 580-586.

Ball, R., and L. Shivakumar (2008), 'Earnings Quality at Initial Public Offerings'. Journal of Accounting and Economics, Vol 45, pp.324-349.

Bannier, C. E., and C. W. Hirsch (2010), 'The Economic Function of Credit Rating Agencies - What Does the Watchlist Tell us?' Journal of Banking \& Finance, Vol 34, No. 12, pp. 3037-3049.

Barber, B. M., and J. D. Lyon (1996), 'Detecting Abnormal Operating Performance: The Empirical Power and Specification of Test Statistics'. Journal of Financial Economics, Vol 41, No. 3, pp. 359-399.

Barzel, Y., M. Habib, and B. Johnsen (2006), 'Prevention is Better Than Cure: Precluding information Acquisition in IPOs'. Journal of Business, Vol 79, pp.2911-2923.

Becker, C., M. Defond, J. Jiambalvo, and J. Subramanyam (1998), 'The Effect of Audit Quality on Earnings Management'. Contemporary Accounting Research, Vol 15, No. 1, pp. 1-24.

Bonsall, S., K. Koharki, and M. Neamtiu (2015), 'The Effectiveness of Credit Rating Agency Monitoring: Evidence from Asset Securitizations'. Accounting Review, Vol 90, No. 5, pp. 1779-1810.

Bowen, R. M., S. Rajgopal, and M. Venkatachalam (2008), 'Accounting Discretion, Corporate Governance, and Firm Performance'. Contemporary Accounting Research, Vol 25, No. 2, pp. 351-405.

Burgstahler, D., and I. Dichev (1997), 'Earnings Management to Avoid Earnings Decreases and Losses'. Journal of Accounting and Economics, Vol 24, pp. 99-126.

Cantillo, M., and J. Wright (2000), 'How Do Firms Choose Their Lenders? An Empirical Investigation. The Review of Financial Studies, Vol 13, No. 1, pp. 155-189.

Carhart, M (1997), 'On Persistence in Mutual Fund Performance'. Journal of Finance, Vol 52, No. 1, pp. $57-82$.

Chan, K., and Y. Lo (2011), 'Credit Ratings and Long-Term IPO Performance'. Journal of Economics \& Finance, Vol 35, No. 4, pp. 473-483.

Chen, S.-S., W.-C. Lin, S.-C. Chang, and C.-Y. Lin (2013), 'Information Uncertainty, Earnings Management, and Long-run Stock Performance Following Initial Public Offerings'. Journal of Business Finance \& Accounting, Vol 40, No. 9-10, pp. 1126-1154.

Cheng, M., and M. Neamtiu (2009), 'An Empirical Analysis of Changes in Credit Rating Properties: Timeliness, Accuracy and Volatility'. Journal of Accounting and Economics, Vol 47, No. 1-2, pp. 108-130.

Cheung, C. S., and I. Krinsky (1994), 'Information Asymmetry and the Underpricing of Initial Public Offerings: Further Empirical Evidence'. Journal of Business Finance \& Accounting, Vol 21 , No. 5, pp. 739-747.

Coffee, J.C. (2006), 'Gatekeepers: The Professions and Corporate Governance': Oxford, Oxford University Press.

Cohen, D. A., A. Dey, and T. Z. Lys (2008), 'Real and Accrual-Based Earnings Management in the Pre- and Post-Sarbanes-Oxley Periods'. Accounting Review, Vol 83, No. 3, pp. 757-787.

Cohen, D. A., and P. Zarowin (2010), 'Accrual-Based and Real Earnings Management Activities Around Seasoned Equity Offerings'. Journal of Accounting and Economics, Vol 50, No. 1, pp. 2-19. 
Darrough, M., and S. Rangan (2005), 'Do Insiders Manipulate Earnings When They Sell Their Shares in an Initial Public Offering?' Journal of Accounting Research, Vol 43, No. 1, pp. 1-33.

Dechow, P (1994), 'Accounting Earnings and Cash Flows as Measures of Firm Performance: The Role of Accounting Accruals'. Journal of Accounting and Economics, Vol 18, No. 1, pp. 3-42.

Dechow, P., R. Sloan, and A. Sweeney (1995), 'Detecting Earnings Management. The Accounting Review, Vol 70, No. 2, pp. 193-225.

Dechow, P. M., and I. D. Dichev (2002), 'The Quality of Accruals and Earnings: The Role of Accrual Estimation Errors'. The Accounting Review, Vol 77, pp. 35-59.

Dechow, P. M., S. P. Kothari, and R. L. Watts (1998), 'The Relation Between Earnings and Cash Flows'. Journal of Accounting and Economics, Vol 25, No. 2, pp. 133-168.

DeFond, M. L., and J. Jiambalvo (1994), 'Debt Convenant Violation and Manipulation of Accruals'. Journal of Accounting \& Economics, Vol 17, pp. 145-176.

Degeorge, F., J. Patel, and R. Zeckhauser (1999), 'Earnings Management to Exceed Thresholds'. Journal of Business, Vol 72, pp. 1-33.

Denis, D. J., and V. T. Mihov (2003), 'The Choice Among Bank Debt, non-Bank Private Debt and Public Debt: Evidence from New Corporate Borrowings'. Journal of Financial Economics, Vol 70, No. 1, pp. 3-28.

Dichev, I. D., and J. D. Piotroski (2001), 'The Long-Run Stock Returns following Bond Ratings Changes'. The Journal of Finance, Vol 56 (1), pp. 173-203.

DuCharme, L., L., P.H. Malatesta, and S.E. Sefcik (2001), 'Earnings Management: IPO Valuation and Subsequent Performance'. Journal of Accounting, Auditing and Finance, Vol 16, pp. 369-396.

DuCharme, L., P. Malatesta, and S. Sefcik (2004), 'Earnings Management, Stock Issues and Shareholder Lawsuits'. Journal of Financial Economics, Vol 71 (1), pp. 27-49.

Dutta, S., and B. Trueman (2002), 'The Interpretation of Information and Corporate Disclosure Strategies'. Review of Accounting Studies, Vol 7 (1), pp. 75-96.

Dye, R. A (1988), 'Earnings Management in an Overlapping Generations Model'. Journal of Accounting Research, Vol 26 (2), pp. 195-235.

Fama, E. (1998), 'Market Efficiency, Long Term Returns and Behavioral Finance'. Journal of Financial Economics, Vol 49, pp. 283-306.

Fama, E., and K. French (1993), 'Common Risk Factors in the Returns on Bonds and Stocks'. Journal of Financial Economics, Vol 33, pp. 3-56.

Fan, Q. (2007), 'Earnings Management and Ownership Retention for Initial Public Offering Firms: Theory and Evidence Accounting Review, Vol 82, No. 1, pp. 27-64.

Faulkender, M., and M. Petersen (2006), 'Does the Source of Capital Affect Capital Structure? ' Review of Financial Studies, Vol 19, pp. 45-79.

Fields, T. D., T. Z. Lys, and L. Vincent (2001), 'Empirical Research on Accounting Choice'. Journal of Accounting and Economics, Vol 31, No. 1-3, pp. 255-307.

Fishman, M. J., and K. M. Hagerty (2003), 'Mandatory Versus Voluntary Disclosure in Markets with Informed and Uninformed Customers'. Journal of Law, Economics, and Organization, Vol 19, No. 1, pp. 45-63.

Francis, J., R. LaFond, P. Olsson, and K. Schipper (2005), 'The Market Pricing of Accruals Quality'. Journal of Accounting and Economics, Vol 39, No. 2, pp. 295-327.

Franz, D., H. HassabElnaby, and G. Lobo (2014), 'Impact of Proximity to Debt Covenant Violation on Earnings Management'. Review of Accounting Studies, Vol 19, No. 1, pp. 473-505.

Friedlan, J. (1994), 'Accounting Choices of Issuers of Initial Public Offerings'. Contemporary Accounting Research, Vol 11, pp. 1-31.

Gramlich, J., and O. Sorensen (2004), 'Voluntary Management Earning Forecasts and Discretionary Accruals: Evidence from Danish IPOs'. European Accounting Review, Vol 13, No. 2, pp. 235-259.

Guay, W. R., S. Kothari, and R. L. Watts (1996), 'A Market Based Evalaution of Discretionary Accruals Model'. Journal of Accounting Research, Vol 34, pp. 183-105.

Gul, F. A., S. Y. K. Fung, and B. Jaggi (2009), 'Earnings Quality: Some Evidence on the Role of Auditor Tenure and Auditors' industry Expertise'. Journal of Accounting and Economics, Vol 47, No. 3, pp. 265-287.

Hand, J., R. Holthausen, and R. Leftwich (1992), 'The Effect of Bond Rating Agency Announcements on Bond and Stock Prices'. Journal of Finance, Vol 57, pp. 733-752.

Healy, P. M., and K. G. Palepu (1993), 'The Effect of Firms Financial Disclosure Strategies on Stock Prices'. Accounting Horizons, Vol 7, pp. 1-11. 
Healy, P. M., and J. M. Wahlen (1999), 'A Review of the Earning Management Literature and its Implication for Standard and Setting'. Accounting Horizons, Vol 13, pp. 365-383.

Heckman, J. (1979), Sample Selection Bias as a Specification Error'. Econometrica, Vol 47, pp. 153-161.

Herbohn, K., I. Tutticci, and P. S. Khor (2010), 'Changes in Unrecognised Deferred Tax Accruals from CarryForward Losses: Earnings Management or Signalling?' Journal of Business Finance \& Accounting, Vol 37, No. 7-8, pp. 763-791.

Hochberg, Y. V. (2012), 'Venture Capital and Corporate Governance in the Newly Public Firm'. Review of Finance, Vol 16, No. 2, pp. 429-480.

Holthausen, R. W., and R. W. Leftwich (1986), 'The Effect of Bond Rating Changes on Common Stock Prices'. Journal of Financial Economics, Vol 17, No. 1, pp. 57-89.

Hribar, P., and D. W. Collins (2002), 'Errors in Estimating Accruals: Implications for Empirical Research'. Journal of Accounting Research, Vol 40, No. 1, pp. 105-134.

Jensen, M. C., and W. H. Meckling (1976), 'Theory of the firm: Managerial behavior, agency costs and Ownership Structure'. Journal of Financial Economics, Vol 3, No. 4, pp. 305-360.

Jo, H., Y. Kim, and M. Park (2007), 'Underwriter Choice and Earnings Management: Evidence from Seasoned Equity Offerings'. Review of Accounting Studies, Vol 12, No. 1, pp. 23-59.

Johnson, S. A (1997), 'An Empirical Analysis of the Determinants of Corporate Debt Ownership Structure'. The Journal of Financial and Quantitative Analysis, Vol 32, No. 1, pp. 47-69.

Jones, J. J. (1991), 'Earnings Management During Import Relief Investigations'. Journal of Accounting Research, Vol 37, pp. 55-81.

Jorion, P., Z. Liu, and C. Shi (2005), 'Informational Effects of Regulation FD: Evidence from Rating Agencies'. Journal of Financial Economics, Vol 76, , No. 2, pp. 309-330.

Jorion, P., C. Shi, and S. Zhang (2009), 'Tightening Credit Standards: The Role of Accounting Quality'. Review of Accounting Studies, Vol 14, No. 1, pp.123-160.

Kallunki, J.-P., and M. Martikainen (2003), 'Earnings Management as a Predictor of Future Profitability of Finnish Firms'. European Accounting Review, Vol 12, No. 2, pp. 311-325.

Karampatsas, N., D. Petmezas, and N. G. Travlos (2014), 'Credit Ratings and the Choice of Payment Method in Mergers and Acquisitions'. Journal of Corporate Finance, Vol 25 (0), pp. 474-493.

Klein, A. (2002), 'Audit Committee, Board of Director Characteristics and Earnings Management'. In Journal of Accounting and Economics, pp. 375-400.

Kothari, S. P., A. J. Leone, and C. E. Wasley (2005), 'Performance Matched Discretionary Accrual Measures'. Journal of Accounting and Economics, Vol 39, No. 1, pp. 163-197.

Kouwenberg, R., and P. Thontirawong (2015), 'Group Affiliation and Earnings Management of Asian IPO Issuers'. Review of Quantitative Finance and Accounting, pp. 1-21.

Krishnan, G. V. (2003), 'Does Big 6 Auditor Industry Expertise Constrain Earnings Management? Accounting Horizons (Suppl.) Group Affiliation and Earnings Management of Asian IPO issuers', pp. 1-16.

Lee, G., and R. W. Masulis (2011), 'Do More Reputable Financial Institutions Reduce Earnings Management by IPO Issuers?' Journal of Corporate Finance, Vol 17, No. 4, pp. 982-1000.

Lo, K (2008), Earnings Management and Earnings Quality'. Journal of Accounting and Economics, Vol 45 , No. 2-3, pp. 350-357.

Lobo, G. J., and J. Zhou (2006), 'Did Conservatism in Financial Reporting Increase after the Sarbanes-Oxley Act? Initial Evidence'. Accounting Horizons, Vol 20, No. 1, pp. 57-73.

Louis, H., and D. Robinson (2005), 'Do Managers Credibly use Accruals to Signal Private Information? Evidence from the Pricing of Discretionary Accruals around Stock Splits'. Journal of Accounting and Economics, Vol 39, No. 2, pp. 361-380.

Marquardt, C. A., and C. I. Wiedman (2004), 'How Are Earnings Managed? An Examination of Specific Accruals'. Contemporary Accounting Research, Vol 21, No. 2, pp. 461-491.

McNichols, M.F (2002), 'The Quality of Accruals and Earnings: The Role of Accrual Estimation Errors: Discussion'. The Accounting Review, Vol 77, pp. 61-69.

Morsfield, S. G., and C. E. L. Tan (2006), 'Do Venture Capitalists Influence the Decision to Manage Earnings in Initial Public Offerings?' Accounting Review, Vol 81, No. 5, pp. 1119-1150.

Ritter, J. R (1991), 'The Long-Run Performance of Initial Public Offerings'. Journal of Finance, Vol 46, No. 1, pp. 3-27.

Roosenbloom, P., and T. Van De Goot (2003), 'Takeover Defences and IPO Firm Value in the Netherlands'. European Financial Management, Vol 9, No. 4, pp. 484-511. 
Roosenboom, P., T. van der Goot, and G. Mertens (2003), 'Earnings Management and Initial Public Offerings: Evidence from the Netherlands'. International Journal of Accounting, Vol 38, No. 3, pp. 243-266.

Roychowdhury, S (2006), 'Earnings Management through Real Activities Manipulation'. Journal of Accounting and Economics, Vol 42, No. 3, pp. 335-370.

Subramanyam, K (1996), 'The Pricing of Discretionary Accruals'. Journal of Accounting and Economics, Vol 22, pp. 249-281.

Suijs, J (2007), 'Voluntary Disclosure of Information when Firms are Uncertain of Investor Response'. Journal of Accounting and Economics, Vol 43, No. 2-3, pp. 391-410.

Teoh, S., I. Welch, and T. Wong (1998a), 'Earnings Management and the Long-Run Market Performance of Initial Public Offerings'. Journal of Finance, Vol 53, pp. 1935-1974.

Teoh, S. H., T. J. Wong, and G. R. Rao (1998b), 'Are Accruals During Initial Public Offerings Opportunistic?' Review of Accounting Studies, Vol 3, pp. 175-208.

Thomadakis, S., D. Gounopoulos, C. Nounis, and A. Merikas (2016), 'Collateral regulation and IPO specific rebelarization: The case or price limits in the Athens Stock Exchange'. European Financial Management, Vol 22, No 2, pp. 276-312

Trueman, B., and S. Titman (1988), 'An Explanation for Accounting Income Smoothing'. Journal of Accounting Research, Vol 26, pp. 127-139.

Venkataraman, R., J. P. Weber, and M. Willenborg (2008), 'Litigation Risk,Audit Quality, and Audit Fees: Evidence from Initial Public Offerings'. Accounting Review, Vol 83, No. 5, pp. 1315-1345.

Watts, R. L., and J. L. Zimmerman (1978), 'Towards a Positive Theory of the Determination of Accounting Standards'. Accounting Review, Vol 53 (1), pp. 112-134.

Wongsunwai, W (2013), 'The Effect of External Monitoring on Accrual-Based and Real Earnings Management: Evidence from Venture-Backed Initial Public Offerings'. Contemporary Accounting Research, Vol 30, No. 1, pp. 296-324. 


\section{Appendix A: Variable definition}

\section{Variable}

\section{Definition}

\section{Measures of earnings management}

Abnormal accruals

Abnormal accruals computed using the modified Jones (1991) model and adjusted for abnormal accruals of a performance-matched non-IPO firm following Kothari et al. (2005). Details of the methodology are described in Appendix B.

Abnormal cash flow from operations

Abnormal cash flow from operations estimated using the model developed by Dechow et al. (1998) and implemented by Roychowdhury (2006). The value is multiplied by minus one. Details of the methodology are described in Appendix B.

Abnormal production costs

Abnormal discretionary expenses

REM1

REM2

\section{Credit rating variables}

Rating existence

Rating level

\section{Firm and offering characteristics}

Firm age

\section{Market value \\ Leverage \\ Loss}

\section{CAPEX}

ROA

$\mathrm{CFO}$

Industry-adjusted ROA
Abnormal production costs estimated using the model developed by Dechow et al. (1998) and implemented by Roychowdhury (2006). Details of the methodology are described in Appendix B.

Abnormal discretionary expenses estimated using the model developed by Dechow et al. (1998) and implemented by Roychowdhury (2006). The value is multiplied by minus one. Details of the methodology are described in Appendix B.

Aggregate level of real earnings management computed as the total of abnormal production costs and abnormal discretionary expenses.

Aggregate level of real earnings management computed as the total of abnormal cash flow from operations and abnormal discretionary expenses.

Indicator variable that equals to one if the firm has a credit rating one month prior to the offering, and zero otherwise.

Credit rating level that ranges from 1 (D rating) to 22 (AAA rating).

Age of the firm in years. Firm age is the difference between the firm's offering year and its founding year. Company founding years are collected from the Field-Ritter dataset. ${ }^{9}$

Market value of the firm at the time of the listing.

Ratio of total liabilities to total assets.

Indicator variable that equals to one if the firm has negative earnings before interest and taxes in the fiscal year prior to the offering, and zero otherwise.

Average capital expenditures in the offering year and one year after scaled by total assets at the beginning of the offering year.

Ratio of net income to total assets.

Ratio of cash flow from operations to total assets.

Industry-adjusted ROA that is calculated by subtracting the median ROA of the two-digit SIC industry group from the firm's ROA.

\footnotetext{
${ }^{9}$ The Field-Ritter dataset is available on Jay Ritter's webpage: http://bear.warrington.ufl.edu/ritter/FoundingDates.htm.
} 
Big6 auditor

Venture capitalist

Highly ranked underwriter

Book-to-market

High-tech industry

\section{Stock returns variables}

Underpricing

BHAR

\section{Market BHR \\ POSEM}

NEGEM

MKT

SMB

HML

\section{Instrumental variables}

Industry fraction

Industry level

Industry profitability

Industry risk
Indicator variable that equals to one if the firm is audited by a big six accounting firm, and zero otherwise. Big six accounting firms include Arthur Andersen, Coopers \& Lybrand, Ernst \& Young, Deloitte \& Touche, KPMG, and PricewaterhouseCoopers. ${ }^{10}$

Indicator variable that equals to one if the firm is venture backed, and zero otherwise.

Indicator variable that equals to one if the firm is underwritten by reputable underwriters, and zero otherwise. Reputable underwriters are those with a ranking score of 9.0 or above based on Jay Ritter's underwriter rankings. ${ }^{11}$

Ratio of book value to market value at the end of the fiscal year of the offering.

Indicator variable that equals to one if the firm is in the high-tech industry, and zero otherwise.

Initial returns on the first trading day.

Post-issue three-year buy-and-hold abnormal return that is calculated starting from the day after the annual financial report in the offering year to the earlier of the three year anniversary date and the delisting date.

Three-year buy-and-hold value weighted market index return.

Monthly return of the portfolio of IPO firms that undertake incomeincreasing EM in the offering year.

Monthly return of the portfolio of IPO firms that undertake incomedecreasing EM in the offering year.

Excess monthly return on the value-weighted CRSP index.

Difference in the monthly returns of value-weighted portfolios of small and large stocks.

Difference in the monthly returns of value-weighted portfolios of high book-to-market stocks and low book-to-market stocks.

Logarithm of one plus the percentage of firms having credit ratings in the same three-digit SIC industry as the IPO firm.

Median credit rating level of firms having credit ratings in the same threedigit SIC industry as the IPO firm.

Median ratio of earnings before interest, taxes, depreciation and amortization (EBITDA) to total assets of firms in the same three-digit SIC industry as the IPO firm.

Standard deviation of the ratio of earnings before interest, taxes, depreciation and amortization (EBITDA) to total assets of firms in the same three-digit SIC industry as the IPO firm.

\footnotetext{
${ }^{10}$ Coopers \& Lybrand merged with Pricewaterhouse on July 1, 1998. Arthur Andersen ceased to operate after Enron scandal in 2002

${ }^{11}$ IPO underwriter reputation rankings are available on Jay Ritter's webpage: http://bear.warrington.ufl.edu/ritter/ipodata.htm.
} 


\section{Appendix B: Earnings management estimation models}

\section{Accrual-based earnings management}

In measuring our estimate of abnormal accruals, we use the modified Jones (1991) model described in Dechow et al. (1995). Jones (1991) assumes that the change in sales and gross property, plant, and equipment (PPE) are two main determinants of the firm's accruals. Thus, total accruals are modelled as a function of sales growth and PPE. The total accruals are disaggregated into two components: expected accruals and abnormal accruals. The expected accruals reflect the firm's economic conditions and are predicted by the change in sales and PPE. The abnormal accruals reflect managerial discretion and are determined by the residuals. However, sales revenues are susceptible to managerial manipulation as managers can influence credit policies to induce sales. Therefore, Dechow et al. (1995) enhance the power of the Jones model by deducting accounts receivable growth from revenue growth to account for the possibility of management manipulation in credit sales.

In applying the modified Jones model, we first estimate for each year the following Jones model cross-sectionally for all firms in the same two-digit SIC industry as the IPO firm yet excluding firms going public in three years' time:

$$
\frac{T A C C_{i . t}}{T A_{i, t-1}}=\beta_{0} \frac{1}{T A_{i, t-1}}+\beta_{1} \frac{\Delta S A L E S_{i, t}}{T A_{i, t-1}}+\beta_{2} \frac{P P E_{i, t}}{T A_{i, t-1}}+\varepsilon_{i, t}
$$

where $T A C C_{i, t}$ is total accruals computed as earnings before extraordinary items and discontinued operations less cash flow from operations; $T A_{i . t-1}$ is lagged total assets; $\triangle S A L E S_{i, t}$ is the change in total sales from the fiscal year before the offering to the fiscal year of the IPO; and $P P E_{i, t}$ is the gross value of property, plant, and equipment. We use the cash flow method instead of the balance sheet approach to measure total accruals, as Hribar and Collins (2002) show that measuring accruals directly from the statement of cash flows is a superior method to avoid the non-articulation problem of the balance sheet approach. All variables are winsorised at the 1 and 99 percentile level to mitigate the influence of outliers. We require at least 10 firms in an industry in a year to run the regressions. This cross-sectional approach, which is introduced by DeFond and Jiambalvo (1994), helps control for changes in economic conditions for specific years and industries that may influence total accruals independent of any managerial manipulation. The coefficient estimates from Equation (B1) are then used to estimate the expected component of total accruals $\left(N A C C_{i . t}\right)$ for the IPO sample as follows:

$$
N A C C_{i . t}=\hat{\beta}_{0} \frac{1}{T A_{i, t-1}}+\hat{\beta}_{1} \frac{\Delta S A L E S_{i, t}-\Delta R E C_{i, t}}{T A_{i, t-1}}+\hat{\beta}_{2} \frac{P P E_{i . t}}{T A_{i, t-1}}
$$


where $\triangle R E C_{i . t}$ is the change in receivables from the fiscal year before the offering to the fiscal year of the IPO. The abnormal accruals $\left(D A C C_{i . t}\right)$ are computed as the difference between total accruals and expected accruals:

$$
D A C C_{i, t}=\frac{T A C C_{i, t}}{T A_{i, t-1}}-N A C C_{i, t}
$$

Several studies raise the concerns that the abnormal accruals measured using the Jones model are correlated with firm performance; therefore, the Jones model is mis-specified when being applied to firms experiencing extreme performance (Dechow et al. 1995). To mitigate this problem, we apply the procedure suggested by Kothari et al. (2005) to match abnormal accruals of the IPO firm to those of a non-IPO counterpart in the same two-digit SIC industry and year with the closest prior-year ROA. We exclude firms whose matched non-IPO firm has ROA outside the range of $+/-10 \%$ of the IPO firm's ROA. The matched firm's abnormal accruals are deducted from the IPO firm's abnormal accruals to yield the performance-matched abnormal accruals for the IPO firm.

We also acknowledge that accruals models may not adequately isolate between abnormal and normal accruals; as a result, estimated abnormal accruals may capture normal components of accruals. However, it should be noted that we use abnormal accruals as a dependent variable. The effect of measurement error on the dependent variable is less severe than on the independent variable. If our estimate of abnormal accruals suffers from measurement error, the consequences will be lower explanatory power $\left(R^{2}\right)$ of the model but unbiased estimated coefficients, larger estimated standard errors, and hence wider confidence intervals.

For robustness check, we employ another commonly used model by Dechow and Dichev (2002) to measure abnormal accruals. Dechow and Dichev (2002) map short-term working capital accruals to present, past, and future cash flows based on the notion that accruals predict future cash receipt or payment. Their model does not address distortions caused by long-term accruals; therefore, we follow McNichols (2002) and Francis et al. (2005) to modify the model by adding growth in revenue and PPE to reflect performance and depreciation. We estimate the following regression cross-sectionally for each year and for all non-IPO firms in each two-digit SIC industry with at least 10 firms:

$$
\frac{T C A_{i . t}}{T A_{i . t-1}}=\beta_{0} \frac{1}{T A_{i . t-1}}+\beta_{1} \frac{C F O_{i . t-1}}{T A_{i . t-1}}+\beta_{2} \frac{C F O_{i . t}}{T A_{i . t-1}}+\beta_{3} \frac{C F O_{i, t+1}}{T A_{i . t-1}}+\beta_{4} \frac{\Delta S A L E S_{i, t}}{T A_{i, t-1}}+\beta_{5} \frac{P P E_{i, t}}{T A_{i . t-1}}+\varepsilon_{i . t}
$$

where

$$
\begin{aligned}
& T C A_{i, t}=\left(\Delta C A_{i, t}-\Delta \operatorname{Cash}_{i, t}\right)-\left(\Delta C L_{i, t}-\Delta S T D_{i, t}\right) \\
& C F O_{i, t}=N I B E_{i, t}-\left(T C A_{i, t}-D E P N_{i, t}\right)
\end{aligned}
$$


where $T C A_{i, t}$ is total current working capital accruals; $C F O_{i, t}$ is cash flow from operations; $T A_{i, t-1}$ is lagged total assets; $\triangle S A L E S_{i, t}$ is the change in sales; $P P E_{i, t}$ is the gross value of plant, property, and equipment; $\Delta C A_{i, t}$ is the change in current assets; $\Delta C a s h_{i, t}$ is the change in cash; $\Delta C L_{i, t}$ is the change in current liabilities; $\triangle S T D_{i, t}$ is the change in short-term debt; $N I B E_{i, t}$ is net income before extraordinary items; and $D E P N_{i, t}$ is depreciation and amortisation expenses. All changes are from the fiscal year before the offering to the fiscal year of the IPO. We winsorise all variables at the 1 and 99 percentile level to moderate the effect of outliers. The estimated coefficients of Equation (B4) are used to estimate the normal level of current accruals of IPO firms. The IPO firms' abnormal current accruals are then computed as the difference between the firms' actual total current accruals and their normal level of current accruals.

\section{Real earnings management}

We measure our real EM proxies based on models developed by Dechow et al. (1998) and implemented by Roychowdhury (2006). Roychowdhury (2006) documents that managers avoid reporting annual earnings losses by manipulating real activities including temporarily increasing sales through price discounts or more lenient credit terms, overproducing to decrease the cost of goods sold, and reducing discretionary expenditures. Therefore, if managers exercise their discretion in operating decisions related to sales, production, and discretionary expenses to boost earnings, firms will exhibit unusually low levels of cash flow from operations and discretionary expenses, and unusually high production costs. We use three metrics as proxies for real EM: abnormal cash flow from operations, abnormal production costs, and abnormal discretionary expenses.

The normal level of cash flow from operations is expressed as a linear function of sales and change in sales in the current period:

$$
\frac{C F O_{i, t}}{T A_{i, t-1}}=\beta_{0} \frac{1}{T A_{i, t-1}}+\beta_{1} \frac{\operatorname{SALES}_{i, t}}{T A_{i, t-1}}+\beta_{2} \frac{\Delta S A L E S_{i, t}}{T A_{i, t-1}}+\varepsilon_{i, t}
$$

where $C F O_{i, t}$ is cash flows from operations, $T A_{i, t-1}$ is lagged total assets, $S A L E S_{i, t}$ is total sales, $\triangle S A L E S_{i, t}$ is the change in sales from the fiscal year before the issue to the fiscal year of the IPO.

The model for normal production costs is estimated as a function of current sales, change in current sales, and change in past sales:

$$
\frac{\operatorname{PROD}_{i, t}}{T A_{i, t-1}}=\beta_{0} \frac{1}{T A_{i, t-1}}+\beta_{1} \frac{\operatorname{SALES}_{i, t}}{T A_{i, t-1}}+\beta_{2} \frac{\Delta S A L E S_{i, t}}{T A_{i, t-1}}+\beta_{3} \frac{\Delta S A L E S_{i, t-1}}{T A_{i, t-1}}+\varepsilon_{i, t}
$$


where $P R O D_{i, t}$ is the production costs computed as the sum of the cost of goods sold and the change in inventory from the fiscal year before the IPO to the fiscal year of the issue. $\triangle S A L E S_{i, t-1}$ is the change in sales from the fiscal year two years before the issue to the fiscal year prior to the IPO.

The normal discretionary expenses are expressed as a linear function of lagged sales:

$$
\frac{\operatorname{DISEXP}_{i, t}}{T A_{i, t-1}}=\beta_{0} \frac{1}{T A_{i, t-1}}+\beta_{1} \frac{\operatorname{SALES}_{i, t-1}}{T A_{i, t-1}}+\varepsilon_{i, t}
$$

where DISEXP ${ }_{i, t}$ is the discretionary expenses computed as the sum of SG\&A, R\&D, and advertising expenses. SALES $S_{i, t-1}$ is total sales in the fiscal year prior to the IPO.

All the three equations (B5), (B6) and (B7) are estimated cross-sectionally for each industryyear with at least 10 observations. We winsorise all variables at the 1 and 99 percentile level to mitigate the issue of outliers. The abnormal level of each real EM proxy is calculated as actual level minus the normal level estimated using the coefficients from the regressions (B5), (B6), and (B7). Moreover, we match real EM measures of the IPO firms to those of non-IPO peers based on year, industry, and ROA to generate performance-matched real EM measures. It is also noted that we multiply the estimated abnormal cash flow from operations and abnormal discretionary expenses by minus one so that higher values reflect higher real EM. Besides analysing the individual effect of each real EM activity, we also measure the aggregate effect of all three metrics by calculating two combined measures $R E M 1$ and REM2. Following (Cohen and Zarowin (2010)), we compute REM1 as the sum of abnormal production costs and abnormal discretionary expenses and REM2 as the sum of abnormal cash flow from operations and abnormal discretionary expenses. Abnormal production costs and abnormal cash flows from operations are not combined because the same activities that create high abnormal production costs also create low abnormal cash flow from operations, so adding the two measures would result in double counting (Roychowdhury 2006; Cohen and Zarowin 2010). The higher REM1, the more likely that firms increase production and cut discretionary expenses to manipulate earnings upward. Similarly, the higher REM2, the more likely that firms manipulate sales and reduce discretionary expenses to report higher earnings. 
Table 1

IPO distribution by issue year, industry, and credit rating level

Panel A: IPO distribution by issue year

\begin{tabular}{|c|c|c|c|c|c|c|}
\hline \multirow{3}{*}{ Year } & \multicolumn{2}{|c|}{ All IPOs } & \multicolumn{2}{|c|}{ Rated IPOs } & \multicolumn{2}{|c|}{ Unrated IPOs } \\
\hline & \multicolumn{2}{|c|}{$(N=2,602)$} & \multicolumn{2}{|c|}{$(N=153)$} & \multicolumn{2}{|c|}{$(N=2,449)$} \\
\hline & $N$ & $\%$ & $N$ & $\%$ & $N$ & $\%$ \\
\hline 1991 & 111 & 4.01 & 7 & 4.38 & 104 & 3.98 \\
\hline 1992 & 185 & 6.68 & 9 & 5.63 & 176 & 6.74 \\
\hline 1993 & 226 & 8.16 & 14 & 8.75 & 212 & 8.12 \\
\hline 1994 & 186 & 6.71 & 4 & 2.50 & 182 & 6.97 \\
\hline 1995 & 214 & 7.72 & 9 & 5.63 & 205 & 7.85 \\
\hline 1996 & 301 & 10.86 & 11 & 6.88 & 290 & 11.11 \\
\hline 1997 & 213 & 7.69 & 9 & 5.63 & 204 & 7.81 \\
\hline 1998 & 140 & 5.05 & 6 & 3.75 & 134 & 5.13 \\
\hline 1999 & 243 & 8.77 & 11 & 6.88 & 232 & 8.89 \\
\hline 2000 & 167 & 6.03 & 7 & 4.38 & 160 & 6.13 \\
\hline 2001 & 35 & 1.26 & 2 & 1.25 & 33 & 1.26 \\
\hline 2002 & 40 & 1.44 & 3 & 1.88 & 37 & 1.42 \\
\hline 2003 & 37 & 1.34 & 7 & 4.38 & 30 & 1.15 \\
\hline 2004 & 95 & 3.43 & 10 & 6.25 & 85 & 3.26 \\
\hline 2005 & 80 & 2.89 & 8 & 5.00 & 72 & 2.76 \\
\hline 2006 & 91 & 3.28 & 14 & 8.75 & 77 & 2.95 \\
\hline 2007 & 99 & 3.57 & 5 & 3.13 & 94 & 3.60 \\
\hline 2008 & 12 & 0.43 & 1 & 0.63 & 11 & 0.42 \\
\hline 2009 & 31 & 1.12 & 5 & 3.13 & 26 & 1.00 \\
\hline 2010 & 52 & 1.88 & 10 & 6.25 & 42 & 1.61 \\
\hline 2011 & 44 & 1.59 & 1 & 0.63 & 43 & 1.65 \\
\hline
\end{tabular}

Panel B: IPO distribution by industry

\begin{tabular}{lccccccc}
\hline Industry name & SIC codes & \multicolumn{2}{c}{ All IPOs } & \multicolumn{2}{c}{ Rated IPOs } & \multicolumn{2}{c}{ Unrated IPOs } \\
\cline { 3 - 7 } & & $N$ & $\%$ & $N$ & $\%$ & $N$ & $\%$ \\
\hline Oil and gas & 13 & 48 & 1.84 & 6 & 3.92 & 42 & 1.71 \\
Food products & 20 & 38 & 1.46 & 7 & 4.58 & 31 & 1.27 \\
Chemical products & 28 & 218 & 8.38 & 9 & 5.88 & 209 & 8.53 \\
Manufacturing & $30-34$ & 91 & 3.49 & 16 & 10.45 & 75 & 3.07 \\
Computer equipment \& services & 35,73 & 809 & 31.09 & 13 & 8.5 & 796 & 32.51 \\
Electronic equipment & 36 & 242 & 9.30 & 8 & 5.23 & 234 & 9.55 \\
Scientific instruments & 38 & 193 & 7.42 & 8 & 5.23 & 185 & 7.55 \\
Transportation and public utilities & $40-49$ & 204 & 7.83 & 28 & 18.29 & 176 & 7.18 \\
Wholesale and retail trade & $50-59$ & 312 & 11.99 & 25 & 16.34 & 287 & 11.72 \\
Entertainment services & $70,78,79$ & 51 & 1.96 & 3 & 1.96 & 48 & 1.95 \\
Health services & 80 & 90 & 3.46 & 5 & 3.27 & 85 & 3.47 \\
All others & $10,12,14-17,21-$ & 306 & 11.78 & 25 & 16.34 & 281 & 11.46 \\
& $27,29,37,39,72$, & & & & & 105 & 2,449 \\
Total & $75,76,82,83,87$ & & & & 100 \\
\hline
\end{tabular}


Panel C: IPO distribution by credit rating level

\begin{tabular}{|c|c|c|c|}
\hline $\begin{array}{c}\text { Credit rating } \\
\text { level }\end{array}$ & Rating level & $\begin{array}{l}\text { All rated IPOs } \\
\qquad(N=153)\end{array}$ & $\%$ \\
\hline AAA & 22 & 1 & 0.65 \\
\hline $\mathrm{AA}+$ & 21 & 0 & 0.00 \\
\hline AA & 20 & 0 & 0.00 \\
\hline AA- & 19 & 0 & 0.00 \\
\hline $\mathrm{A}+$ & 18 & 0 & 0.00 \\
\hline $\mathrm{A}$ & 17 & 1 & 0.65 \\
\hline A- & 16 & 1 & 0.65 \\
\hline $\mathrm{BBB}+$ & 15 & 0 & 0.00 \\
\hline BBB & 14 & 2 & 1.31 \\
\hline BBB- & 13 & 1 & 0.65 \\
\hline $\mathrm{BB}+$ & 12 & 2 & 1.31 \\
\hline BB & 11 & 9 & 5.88 \\
\hline BB- & 10 & 27 & 17.65 \\
\hline $\mathrm{B}+$ & 9 & 66 & 43.14 \\
\hline B & 8 & 27 & 17.65 \\
\hline B- & 7 & 12 & 7.84 \\
\hline $\mathrm{CCC}+$ & 6 & 4 & 2.61 \\
\hline $\mathrm{CCC}$ & 5 & 0 & 0.00 \\
\hline $\mathrm{CCC}-$ & 4 & 0 & 0.00 \\
\hline $\mathrm{CC}$ & 3 & 0 & 0.00 \\
\hline $\mathrm{C}$ & 2 & 0 & 0.00 \\
\hline \multirow[t]{6}{*}{$\mathrm{D}$} & 1 & 0 & 0.00 \\
\hline & A rating category & 3 & 1.95 \\
\hline & $\mathrm{B}$ rating category & 146 & 95.43 \\
\hline & $\mathrm{C}$ and $\mathrm{D}$ rating category & 4 & 2.61 \\
\hline & Investment grade (BBB- and above) & 6 & 3.91 \\
\hline & Non-investment grade (BB+ and below) & 147 & 96.08 \\
\hline
\end{tabular}

Table 1 presents the sample distribution of IPO firms over the period 1991-2011 by issue year (Panel A), by industry (Panel B), and by credit rating level (Panel C). Credit rating level is assigned a number from 1 to 22 and a higher rating level takes a higher value. $N$ denotes the number of observations. 
Table 2

Descriptive statistics

\begin{tabular}{|c|c|c|c|c|c|c|c|c|c|c|c|}
\hline & \multicolumn{3}{|c|}{ All IPO firms } & \multicolumn{3}{|c|}{ Unrated IPO firms } & \multicolumn{3}{|c|}{ Rated IPO firms } & \multirow{2}{*}{$\begin{array}{l}\text { Difference } \\
\text { in mean } \\
\text { (p-value) }\end{array}$} & \multirow{2}{*}{$\begin{array}{l}\text { Difference } \\
\text { in median } \\
\text { (p-value) }\end{array}$} \\
\hline & $N$ & Mean & Median & $N$ & Mean & Median & $N$ & Mean & Median & & \\
\hline \multicolumn{12}{|l|}{ Firm characteristics } \\
\hline Firm age & 2,602 & 16.08 & 9.00 & 2,449 & 14.78 & 8.00 & 153 & 36.86 & 24.00 & 0.000 & 0.000 \\
\hline Market value & 2,602 & 445.54 & 184.23 & 2,449 & 395.94 & 171.38 & 153 & $1,252.28$ & 497.43 & 0.000 & 0.000 \\
\hline Leverage & 2,602 & 0.73 & 0.73 & 2,449 & 0.71 & 0.66 & 153 & 0.96 & 0.89 & 0.000 & 0.000 \\
\hline Loss & 2,602 & 0.37 & 0.37 & 2,449 & 0.39 & 0.00 & 153 & 0.08 & 0.00 & 0.000 & 0.000 \\
\hline Highly ranked underwriter & 2,602 & 0.36 & 0.36 & 2,449 & 0.34 & 0.00 & 153 & 0.68 & 1.00 & 0.000 & 0.000 \\
\hline Big6 auditor & 2,602 & 0.92 & 0.92 & 2,449 & 0.92 & 1.00 & 153 & 0.96 & 1.00 & 0.032 & 0.063 \\
\hline Venture capitalist & 2,602 & 0.51 & 0.51 & 2,449 & 0.53 & 1.00 & 153 & 0.18 & 0.00 & 0.000 & 0.000 \\
\hline Industry-adjusted ROA & 2,602 & -0.17 & -0.17 & 2,449 & -0.18 & -0.00 & 153 & -0.01 & -0.01 & 0.000 & 0.534 \\
\hline CAPEX & 2,602 & 0.41 & 0.41 & 2,449 & 0.43 & 0.14 & 153 & 0.12 & 0.07 & 0.112 & 0.000 \\
\hline \multicolumn{12}{|l|}{ Earnings management proxies } \\
\hline Abnormal accruals & 2,324 & $-0.03 * *$ & $0.02 * * *$ & 2,188 & $-0.03 * *$ & $0.03 * * *$ & 136 & -0.04 & -0.01 & 0.480 & 0.060 \\
\hline Abnormal cash flow from operations & 2,354 & $0.10 * * *$ & $0.03 * * *$ & 2,217 & $0.10 * * *$ & $0.03 * * *$ & 137 & -0.00 & 0.02 & 0.052 & 0.165 \\
\hline Abnormal production costs & 1,038 & $-0.11 * * *$ & $-0.08 * * *$ & 938 & $-0.12 * * *$ & $-0.09 * * *$ & 100 & -0.01 & -0.01 & 0.107 & 0.008 \\
\hline Abnormal discretionary expenses & 2,211 & $-0.65 * * *$ & $-0.25 * * *$ & 2,088 & $-0.69 * * *$ & $-0.29 * * *$ & 123 & 0.02 & 0.02 & 0.000 & 0.000 \\
\hline REM1 & 968 & $-0.80 * * *$ & $-0.30 * * *$ & 879 & $-0.88 * * *$ & $-0.40 * * *$ & 89 & 0.06 & $0.08 * *$ & 0.000 & 0.000 \\
\hline REM2 & 2,179 & $-0.56 * * *$ & $-0.21 * * *$ & 2,059 & $-0.59 * * *$ & $-0.24 * * *$ & 120 & 0.02 & 0.01 & 0.000 & 0.000 \\
\hline
\end{tabular}

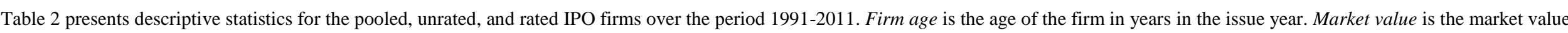

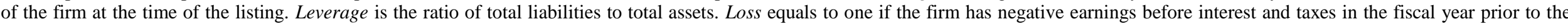

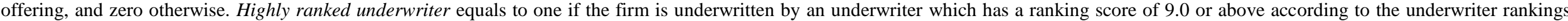

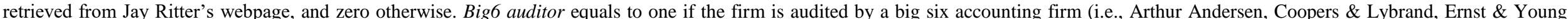

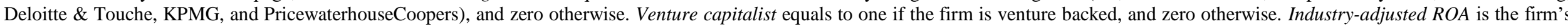

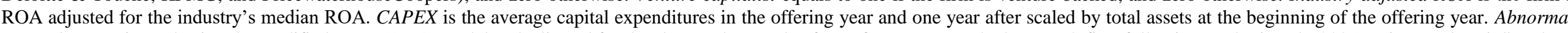

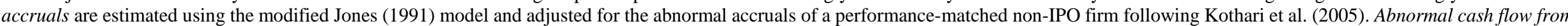

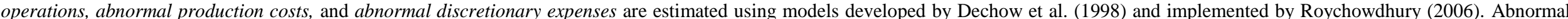

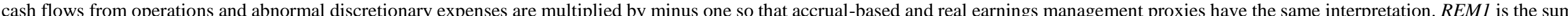

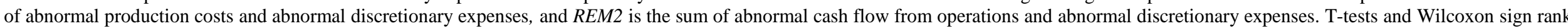

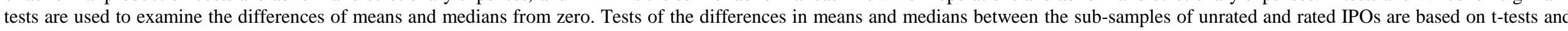
Wilcoxon rank sum tests. One, two and three asterisks denote the statistical significance at the $10 \%, 5 \%$ and $1 \%$ levels, respectively. $N$ denotes the number of observations. 
Table 3

Regressions of accrual-based earnings management on credit rating existence

\begin{tabular}{|c|c|c|c|c|c|c|}
\hline & \multicolumn{2}{|c|}{ Heckman } & \multicolumn{2}{|c|}{ MLE } & \multicolumn{2}{|c|}{ IV } \\
\hline & Selection & Outcome & Selection & Outcome & Selection & Outcome \\
\hline \multirow[t]{2}{*}{ Rating existence } & & $-0.650 * * *$ & & $-0.283 * * *$ & & $-1.207 * *$ \\
\hline & & $(-2.79)$ & & $(-4.58)$ & & $(-2.04)$ \\
\hline \multirow[t]{2}{*}{$\log (1+$ firm age $)$} & & $-0.185^{* * *}$ & & $-0.184 * * *$ & $0.066 * * *$ & $-0.106^{*}$ \\
\hline & & $(-5.32)$ & & $(-5.18)$ & $(2.92)$ & $(-1.79)$ \\
\hline \multirow[t]{2}{*}{ Ln(market value) } & & 0.001 & & 0.001 & $0.044 * * *$ & 0.050 \\
\hline & & $(0.11)$ & & $(0.08)$ & $(4.39)$ & $(1.57)$ \\
\hline \multirow[t]{2}{*}{ Leverage } & & $0.067 * *$ & & $0.063^{*}$ & $0.046 * * *$ & $0.119 * *$ \\
\hline & & $(2.14)$ & & (1.94) & $(2.67)$ & $(2.34)$ \\
\hline \multirow[t]{2}{*}{ Loss } & & $0.074 *$ & & $0.076^{*}$ & 0.006 & 0.078 \\
\hline & & $(1.95)$ & & $(1.72)$ & $(0.28)$ & $(1.60)$ \\
\hline \multirow[t]{2}{*}{ Highly ranked underwriter } & & -0.033 & & -0.036 & 0.017 & -0.014 \\
\hline & & $(-1.10)$ & & $(-1.16)$ & $(0.95)$ & $(-0.36)$ \\
\hline \multirow[t]{2}{*}{ Big6 auditor } & & 0.029 & & 0.029 & 0.008 & 0.035 \\
\hline & & $(0.60)$ & & $(0.69)$ & $(0.35)$ & $(0.72)$ \\
\hline \multirow[t]{2}{*}{ Venture capitalist } & & $-0.056 * *$ & & $-0.049 *$ & $-0.047 * * *$ & $-0.109 * *$ \\
\hline & & $(-2.04)$ & & $(-1.85)$ & $(-3.93)$ & $(-2.54)$ \\
\hline \multirow[t]{2}{*}{ Industry-adjusted ROA } & & 0.002 & & 0.000 & 0.012 & 0.015 \\
\hline & & $(0.04)$ & & $(0.00)$ & $(0.67)$ & $(0.29)$ \\
\hline \multirow[t]{2}{*}{ CAPEX } & & $0.014 * * *$ & & $0.014 * * *$ & -0.001 & $0.013 * * *$ \\
\hline & & $(4.69)$ & & $(3.56)$ & $(-1.39)$ & $(3.61)$ \\
\hline \multirow[t]{2}{*}{ Intercept } & $-2.183 * * *$ & $0.381 * * *$ & $-2.217 * * *$ & $0.357 * * *$ & $-0.284 * * *$ & 0.066 \\
\hline & $(-15.36)$ & $(3.86)$ & $(-17.58)$ & $(4.03)$ & $(-4.71)$ & $(0.35)$ \\
\hline \multirow[t]{2}{*}{ Industry fraction } & $8.235 * * *$ & & $8.564 * * *$ & & $0.533^{* *}$ & \\
\hline & $(6.01)$ & & $(6.86)$ & & $(2.31)$ & \\
\hline \multirow[t]{2}{*}{ Industry profitability } & 0.191 & & 0.288 & & 0.045 & \\
\hline & $(0.19)$ & & $(0.31)$ & & $(0.57)$ & \\
\hline \multirow[t]{2}{*}{ Industry risk } & -0.004 & & -0.003 & & 0.000 & \\
\hline & $(-0.28)$ & & $(-0.48)$ & & $(-1.07)$ & \\
\hline \multirow[t]{2}{*}{ Inverse Mills ratio } & $0.265^{* *}$ & & & & & \\
\hline & $(2.40)$ & & & & & \\
\hline $\begin{array}{l}\text { Likelihood ratio test against } \\
H_{0}: \rho=0 \text { (p-value) }\end{array}$ & & & & 0.000 & & \\
\hline $\begin{array}{l}\text { Durbin-Wu-Hausman test } \\
\text { against } H_{0} \text { : variables are } \\
\text { exogenous } \text { (p-value) }\end{array}$ & & & & & & 0.018 \\
\hline Number of observations & 1,000 & 1,000 & 1,000 & 1,000 & 1,000 & 1,000 \\
\hline
\end{tabular}

Table 3 presents the regression analyses of the association between abnormal accruals and credit rating existence using three estimation approaches: Heckman two-step treatment effect model, maximum likelihood estimation (MLE) treatment effect model, and instrumental variable (IV) model. In the selection equation, rating existence is regressed on industry fraction, industry profitability, and industry risk. Industry fraction is the logarithm of one plus the percentage of firms having credit ratings in the same three-digit SIC industry as the IPO firm. Industry profitability is the median ratio of earnings before interest, taxes, depreciation and amortization (EBITDA) to total assets of firms in the same three-digit SIC industry as the IPO firm. Industry risk is the standard deviation of the ratio of earnings before interest, taxes, depreciation and amortization (EBITDA) to total assets of firms in the same three-digit SIC industry as the IPO firm. The outcome equation is:

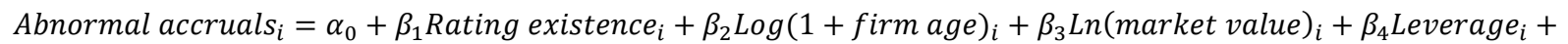
$\beta_{5}$ Loss $_{i}+\beta_{6}$ Highly ranked underwriter $_{i}+\beta_{7}$ Big 6 auditor $_{i}+\beta_{8}$ Venture capitalist $_{i}+\beta_{9}$ Industry adjusted ROA $_{i}+$ $\beta_{10}$ CAPEX $_{i}+\sum_{1991}^{2011} \beta$ Year $+\varepsilon_{i}$ 
The dependent variable Abnormal accruals are estimated using the modified Jones (1991) model and adjusted for the abnormal accruals of a performance-matched non-IPO firm following Kothari et al. (2005). Rating existence equals to one if the firm has a credit rating one month prior to the offering, and zero otherwise. $\log (1+\mathrm{firm}$ age $)$ is the logarithm of one plus firm age in the offering year. Ln(market value) is the natural logarithm of the firm's market value at the time of the listing. Leverage is the ratio of total liabilities to total assets. Loss equals to one if the firm has negative earnings before interest and taxes in the fiscal year prior to the offering, and zero otherwise. Highly ranked underwriter equals to one if the firm is underwritten by an underwriter which has a ranking score of 9.0 or above according to the underwriter rankings retrieved from Jay Ritter's webpage, and zero otherwise. Big6 auditor equals to one if the firm is audited by a big six accounting firm (i.e., Arthur Andersen, Coopers \& Lybrand, Ernst \& Young, Deloitte \& Touche, KPMG, and PricewaterhouseCoopers), and zero otherwise. Venture capitalist equals to one if the firm is venture backed, and zero otherwise. Industryadjusted ROA is the firm's ROA adjusted for the industry's median ROA. CAPEX is the average capital expenditures in the offering year and one year after scaled by total assets at the beginning of the offering year. All regressions control for year fixed effects whose coefficients are suppressed. One, two and three asterisks denote statistical significance at the $10 \%, 5 \%$ and $1 \%$ levels, respectively. The test statistics are shown in parentheses below coefficient estimates. Standard errors are adjusted for heteroskedasticity. 
Table 4

Regressions of real earnings management on credit rating existence

Panel A: Heckman's two-step treatment effect

\begin{tabular}{|c|c|c|c|c|c|c|c|c|c|c|}
\hline & \multicolumn{2}{|c|}{$\begin{array}{c}\text { Abnormal cash flow from } \\
\text { operations }\end{array}$} & \multicolumn{2}{|c|}{ Abnormal production costs } & \multicolumn{2}{|c|}{$\begin{array}{l}\text { Abnormal discretionary } \\
\text { expenses }\end{array}$} & \multicolumn{2}{|c|}{ REM1 } & \multicolumn{2}{|c|}{ REM2 } \\
\hline & Selection & Outcome & Selection & Outcome & Selection & Outcome & Selection & Outcome & Selection & Outcome \\
\hline Rating existence & & $\begin{array}{c}-0.504 * * \\
(-2.38)\end{array}$ & & $\begin{array}{c}-0.671 * * \\
(-2.04)\end{array}$ & & $\begin{array}{c}-0.675 * * * \\
(-2.67)\end{array}$ & & $\begin{array}{c}-0.812 * * \\
(-2.01)\end{array}$ & & $\begin{array}{c}-0.825 * * * \\
(-2.63)\end{array}$ \\
\hline $\log (1+$ firm age $)$ & & $\begin{array}{c}-0.149 * * * \\
(-3.14)\end{array}$ & & $\begin{array}{l}0.056 \\
(0.64)\end{array}$ & & $\begin{array}{l}-0.078 \\
(-1.48)\end{array}$ & & $\begin{array}{l}-0.091 \\
(-0.85)\end{array}$ & & $\begin{array}{l}-0.045 \\
(-0.72)\end{array}$ \\
\hline $\operatorname{Ln}($ market value) & & $\begin{array}{l}0.008 \\
(0.42)\end{array}$ & & $\begin{array}{c}-0.053^{*} \\
(-1.69)\end{array}$ & & $\begin{array}{l}0.031 \\
(1.40)\end{array}$ & & $\begin{array}{c}-0.113 * * * \\
(-2.66)\end{array}$ & & $\begin{array}{l}0.029 \\
(1.10)\end{array}$ \\
\hline Leverage & & $\begin{array}{c}0.089 * * \\
(2.35)\end{array}$ & & $\begin{array}{l}0.024 \\
(0.34)\end{array}$ & & $\begin{array}{c}0.141 * * \\
(2.30)\end{array}$ & & $\begin{array}{l}0.053 \\
(0.50)\end{array}$ & & $\begin{array}{c}0.178 * * * \\
(2.89)\end{array}$ \\
\hline Loss & & $\begin{array}{c}-0.102 * * \\
(-2.08)\end{array}$ & & $\begin{array}{l}0.090 \\
(1.06)\end{array}$ & & $\begin{array}{l}0.073 \\
(1.14)\end{array}$ & & $\begin{array}{l}0.015 \\
(0.14)\end{array}$ & & $\begin{array}{l}0.013 \\
(0.17)\end{array}$ \\
\hline Highly ranked underwriter & & $\begin{array}{c}-0.084 * * \\
(-2.20)\end{array}$ & & $\begin{array}{l}-0.082 \\
(-1.34)\end{array}$ & & $\begin{array}{c}-0.137 * * * \\
(-2.76)\end{array}$ & & $\begin{array}{l}-0.114 \\
(-1.38)\end{array}$ & & $\begin{array}{c}-0.151 * * * \\
(-2.69)\end{array}$ \\
\hline Big6 auditor & & $\begin{array}{l}0.023 \\
(0.36)\end{array}$ & & $\begin{array}{l}0.153 \\
(1.54)\end{array}$ & & $\begin{array}{l}0.069 \\
(0.88)\end{array}$ & & $\begin{array}{l}0.156 \\
(1.15)\end{array}$ & & $\begin{array}{l}-0.024 \\
(-0.27)\end{array}$ \\
\hline Venture capitalist & & $\begin{array}{c}-0.066^{*} \\
(-1.76)\end{array}$ & & $\begin{array}{l}0.009 \\
(0.12)\end{array}$ & & $\begin{array}{l}-0.035 \\
(-0.71)\end{array}$ & & $\begin{array}{l}-0.066 \\
(-0.66)\end{array}$ & & $\begin{array}{l}-0.053 \\
(-0.94)\end{array}$ \\
\hline Industry-adjusted ROA & & $\begin{array}{c}-0.716 * * * \\
(-17.75)\end{array}$ & & $\begin{array}{c}-0.478 * * * \\
(-6.07)\end{array}$ & & $\begin{array}{c}-0.264 * * * \\
(-3.30)\end{array}$ & & $\begin{array}{c}-0.355^{* * * *} \\
(-2.95)\end{array}$ & & $\begin{array}{c}-0.241 * * * \\
(-3.75)\end{array}$ \\
\hline CAPEX & & $\begin{array}{l}0.018 * * * \\
(4.55)\end{array}$ & & $\begin{array}{l}0.277 * * * \\
(4.18)\end{array}$ & & $\begin{array}{l}0.007 \\
(0.28)\end{array}$ & & $\begin{array}{c}0.232 * \\
(1.80)\end{array}$ & & $\begin{array}{c}0.034 * * * \\
(2.89)\end{array}$ \\
\hline Intercept & $\begin{array}{c}-2.248 * * * \\
(-17.73)\end{array}$ & $\begin{array}{c}0.311^{* *} \\
(2.33)\end{array}$ & $\begin{array}{c}-1.778 * * * \\
(-10.80)\end{array}$ & $\begin{array}{l}0.478 \\
(1.59)\end{array}$ & $\begin{array}{c}-1.954 * * * \\
(-13.06)\end{array}$ & $\begin{array}{l}0.196 \\
(1.21)\end{array}$ & $\begin{array}{c}-1.515 * * * \\
(-8.60)\end{array}$ & $\begin{array}{c}1.261 * * * \\
(3.10)\end{array}$ & $\begin{array}{c}-2.004 * * * \\
(-14.12)\end{array}$ & $\begin{array}{l}0.262 \\
(1.44)\end{array}$ \\
\hline Industry fraction & $\begin{array}{c}9.438 * * * \\
(7.46)\end{array}$ & & $\begin{array}{c}6.732 * * * \\
(3.58)\end{array}$ & & $\begin{array}{c}9.418 * * * \\
(5.65)\end{array}$ & & $\begin{array}{c}6.628 * * * \\
(3.26)\end{array}$ & & $\begin{array}{c}8.839 * * * \\
(5.61)\end{array}$ & \\
\hline Industry profitability & $\begin{array}{l}1.027 \\
(1.25)\end{array}$ & & $\begin{array}{l}1.714^{*} \\
(1.81)\end{array}$ & & $\begin{array}{l}-0.290 \\
(-0.33)\end{array}$ & & $\begin{array}{l}1.199 \\
(1.29)\end{array}$ & & $\begin{array}{l}0.081 \\
(0.10)\end{array}$ & \\
\hline Industry risk & $\begin{array}{l}-0.002 \\
(-0.18)\end{array}$ & & $\begin{array}{l}0.005 \\
(0.82)\end{array}$ & & $\begin{array}{l}0.005 \\
(0.95)\end{array}$ & & $\begin{array}{l}0.004 \\
(0.70)\end{array}$ & & $\begin{array}{l}0.005 \\
(0.96)\end{array}$ & \\
\hline Inverse Mills ratio & $\begin{array}{c}0.182 * \\
(1.73)\end{array}$ & & $\begin{array}{c}0.342 * \\
(1.95)\end{array}$ & & $\begin{array}{c}0.292 * * \\
(2.22)\end{array}$ & & $\begin{array}{c}0.409 * \\
(1.81)\end{array}$ & & $\begin{array}{c}0.348 * * \\
(2.18)\end{array}$ & \\
\hline Number of observations & 1,037 & 1,037 & 361 & 361 & 544 & 544 & 266 & 266 & 610 & 610 \\
\hline
\end{tabular}


Panel B: Treatment effect with maximum-likelihood estimation

\begin{tabular}{|c|c|c|c|c|c|c|c|c|c|c|}
\hline 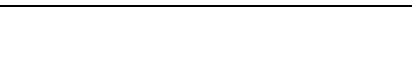 & \multicolumn{2}{|c|}{$\begin{array}{c}\text { Abnormal cash flow from } \\
\text { operations }\end{array}$} & \multicolumn{2}{|c|}{ Abnormal production costs } & \multicolumn{2}{|c|}{$\begin{array}{c}\text { Abnormal discretionary } \\
\text { expenses }\end{array}$} & \multicolumn{2}{|c|}{ REM1 } & \multicolumn{2}{|c|}{ REM2 } \\
\hline & Selection & Outcome & Selection & Outcome & Selection & Outcome & Selection & Outcome & Selection & Outcome \\
\hline Rating existence & & $\begin{array}{c}-0.424 * * * \\
(-5.39)\end{array}$ & & $\begin{array}{c}-0.518 * * * \\
(-4.38)\end{array}$ & & $\begin{array}{c}-0.475 * * * \\
(-5.04)\end{array}$ & & $\begin{array}{c}-0.643 * * * \\
(-3.76)\end{array}$ & & $\begin{array}{c}-0.547 * * * \\
(-5.01)\end{array}$ \\
\hline $\log (1+$ firm age $)$ & & $\begin{array}{c}-0.149 * * * \\
(-3.61)\end{array}$ & & $\begin{array}{l}0.051 \\
(0.67)\end{array}$ & & $\begin{array}{l}-0.080 \\
(-1.64)\end{array}$ & & $\begin{array}{l}-0.093 \\
(-0.96)\end{array}$ & & $\begin{array}{l}-0.047 \\
(-0.82)\end{array}$ \\
\hline $\operatorname{Ln}($ market value $)$ & & $\begin{array}{l}0.007 \\
(0.35)\end{array}$ & & $\begin{array}{c}-0.054^{*} \\
(-1.80)\end{array}$ & & $\begin{array}{l}0.029 \\
(1.20)\end{array}$ & & $\begin{array}{c}-0.116^{* * *} \\
(-2.66)\end{array}$ & & $\begin{array}{l}0.026 \\
(0.94)\end{array}$ \\
\hline Leverage & & $\begin{array}{c}0.088^{*} \\
(1.83)\end{array}$ & & $\begin{array}{l}0.026 \\
(0.35)\end{array}$ & & $\begin{array}{l}0.136 \\
(1.50)\end{array}$ & & $\begin{array}{l}0.051 \\
(0.42)\end{array}$ & & $\begin{array}{c}0.173^{* *} \\
(2.06)\end{array}$ \\
\hline Loss & & $\begin{array}{c}-0.101 * \\
(-1.91)\end{array}$ & & $\begin{array}{l}0.103 \\
(1.14)\end{array}$ & & $\begin{array}{l}0.073 \\
(1.02)\end{array}$ & & $\begin{array}{l}0.028 \\
(0.21)\end{array}$ & & $\begin{array}{l}0.012 \\
(0.15)\end{array}$ \\
\hline Highly ranked underwriter & & $\begin{array}{c}-0.085^{* *} \\
(-2.48)\end{array}$ & & $\begin{array}{l}-0.088 \\
(-1.57)\end{array}$ & & $\begin{array}{c}-0.135 * * * \\
(-2.63)\end{array}$ & & $\begin{array}{l}-0.119 \\
(-1.43)\end{array}$ & & $\begin{array}{c}-0.152 * * * \\
(-2.69)\end{array}$ \\
\hline Big6 auditor & & $\begin{array}{l}0.024 \\
(0.49)\end{array}$ & & $\begin{array}{l}0.150 \\
(1.47)\end{array}$ & & $\begin{array}{l}0.069 \\
(0.95)\end{array}$ & & $\begin{array}{l}0.160 \\
(1.20)\end{array}$ & & $\begin{array}{l}-0.021 \\
(-0.25)\end{array}$ \\
\hline Venture capitalist & & $\begin{array}{l}-0.064^{*} \\
(-1.65)\end{array}$ & & $\begin{array}{l}0.012 \\
(0.20)\end{array}$ & & $\begin{array}{l}-0.032 \\
(-0.63)\end{array}$ & & $\begin{array}{l}-0.066 \\
(-0.64)\end{array}$ & & $\begin{array}{l}-0.049 \\
(-0.78)\end{array}$ \\
\hline Industry-adjusted ROA & & $\begin{array}{c}-0.718 * * * \\
(-10.27)\end{array}$ & & $\begin{array}{c}-0.479 * * * \\
(-4.10)\end{array}$ & & $\begin{array}{c}-0.269 * * \\
(-2.20)\end{array}$ & & $\begin{array}{c}-0.351 * * \\
(-2.29)\end{array}$ & & $\begin{array}{c}-0.247 * * * \\
(-2.58)\end{array}$ \\
\hline CAPEX & & $\begin{array}{l}0.018^{* * *} \\
(2.75)\end{array}$ & & $\begin{array}{l}0.282 * * * \\
(2.72)\end{array}$ & & $\begin{array}{l}0.006 \\
(0.30)\end{array}$ & & $\begin{array}{l}0.237 \\
(1.21)\end{array}$ & & $\begin{array}{c}0.034 * * * \\
(5.11)\end{array}$ \\
\hline Intercept & $\begin{array}{c}-2.251 * * * \\
(-18.60)\end{array}$ & $\begin{array}{c}0.306^{* *} \\
(2.57)\end{array}$ & $\begin{array}{c}-1.817 * * * \\
(-11.51)\end{array}$ & $\begin{array}{c}0.484 * * \\
(2.02)\end{array}$ & $\begin{array}{c}-1.997 * * * \\
(-14.54)\end{array}$ & $\begin{array}{l}0.195 \\
(1.37)\end{array}$ & $\begin{array}{c}-1.554 * * * \\
(-9.55)\end{array}$ & $\begin{array}{c}1.242 * * * \\
(3.73)\end{array}$ & $\begin{array}{c}-2.032 * * * \\
(-14.95)\end{array}$ & $\begin{array}{l}0.252 \\
(1.50)\end{array}$ \\
\hline Industry fraction & $\begin{array}{l}9.538 * * * \\
(7.93)\end{array}$ & & $\begin{array}{l}7.235^{* * * *} \\
(4.21)\end{array}$ & & $\begin{array}{l}10.425 * * * \\
(6.58)\end{array}$ & & $\begin{array}{l}7.320 * * * \\
(4.02)\end{array}$ & & $\begin{array}{l}9.712 * * * \\
(6.09)\end{array}$ & \\
\hline Industry profitability & $\begin{array}{l}1.117 \\
(1.03)\end{array}$ & & $\begin{array}{l}1.997^{*} \\
(1.91)\end{array}$ & & $\begin{array}{l}-0.348 \\
(-0.38)\end{array}$ & & $\begin{array}{l}1.263 \\
(1.30)\end{array}$ & & $\begin{array}{l}-0.122 \\
(-0.14)\end{array}$ & \\
\hline Industry risk & $\begin{array}{l}-0.007 \\
(-1.62)\end{array}$ & & $\begin{array}{l}0.001 \\
(0.33)\end{array}$ & & $\begin{array}{l}-0.001 \\
(-0.31)\end{array}$ & & $\begin{array}{l}0.001 \\
(0.15)\end{array}$ & & $\begin{array}{l}0.000 \\
(0.01)\end{array}$ & \\
\hline $\begin{array}{l}\text { Likelihood ratio test against } H_{0} \text { : } \\
\rho=0 \text { (p-value })\end{array}$ & & 0.000 & & 0.000 & & 0.000 & & 0.000 & & 0.000 \\
\hline Number of observations & 1,037 & 1,037 & 361 & 361 & 544 & 544 & 266 & 266 & 610 & 610 \\
\hline
\end{tabular}


Panel C: Instrumental variable regression

\begin{tabular}{|c|c|c|c|c|c|c|c|c|c|c|}
\hline & \multicolumn{2}{|c|}{$\begin{array}{c}\text { Abnormal cash flow from } \\
\text { operations }\end{array}$} & \multicolumn{2}{|c|}{ Abnormal production costs } & \multicolumn{2}{|c|}{$\begin{array}{c}\text { Abnormal discretionary } \\
\text { expenses }\end{array}$} & \multicolumn{2}{|c|}{ REM1 } & \multicolumn{2}{|c|}{ REM2 } \\
\hline & Selection & Outcome & Selection & Outcome & Selection & Outcome & Selection & Outcome & Selection & Outcome \\
\hline Rating existence & & $\begin{array}{c}-1.525^{*} \\
(-1.82)\end{array}$ & & $\begin{array}{c}-1.592^{*} \\
(-1.91)\end{array}$ & & $\begin{array}{c}-2.122^{* *} \\
(-2.50)\end{array}$ & & $\begin{array}{c}-1.847 * * \\
(-1.98)\end{array}$ & & $\begin{array}{c}-4.055^{* *} \\
(-2.16)\end{array}$ \\
\hline $\log (1+$ firm age $)$ & $\begin{array}{c}0.045^{*} \\
(1.76)\end{array}$ & $\begin{array}{l}-0.079 \\
(-1.23)\end{array}$ & $\begin{array}{l}-0.041 \\
(-0.74)\end{array}$ & $\begin{array}{l}0.000 \\
(0.00)\end{array}$ & $\begin{array}{l}-0.006 \\
(-0.18)\end{array}$ & $\begin{array}{l}-0.076 \\
(-0.94)\end{array}$ & $\begin{array}{l}-0.045 \\
(-0.69)\end{array}$ & $\begin{array}{l}-0.163 \\
(-1.17)\end{array}$ & $\begin{array}{l}0.015 \\
(0.46)\end{array}$ & $\begin{array}{l}0.036 \\
(0.24)\end{array}$ \\
\hline $\operatorname{Ln}($ market value) & $\begin{array}{c}0.050 * * * \\
(5.08)\end{array}$ & $\begin{array}{l}0.080 \\
(1.55)\end{array}$ & $\begin{array}{c}0.070 * * * \\
(3.61)\end{array}$ & $\begin{array}{l}0.059 \\
(0.83)\end{array}$ & $\begin{array}{l}0.040 * * * \\
(3.03)\end{array}$ & $\begin{array}{c}0.113 * * \\
(2.36)\end{array}$ & $\begin{array}{l}0.071 * * * \\
(2.81)\end{array}$ & $\begin{array}{l}0.021 \\
(0.23)\end{array}$ & $\begin{array}{c}0.045^{* * *} \\
(3.33)\end{array}$ & $\begin{array}{c}0.214 * * \\
(1.98)\end{array}$ \\
\hline Leverage & $\begin{array}{c}0.033 * * \\
(2.09)\end{array}$ & $\begin{array}{c}0.137 * * \\
(2.16)\end{array}$ & $\begin{array}{l}0.105 * * * \\
(2.66)\end{array}$ & $\begin{array}{l}0.197 \\
(1.41)\end{array}$ & $\begin{array}{c}0.114 * * * \\
(3.02)\end{array}$ & $\begin{array}{c}0.382 * * \\
(2.36)\end{array}$ & $\begin{array}{c}0.147 * * \\
(2.31)\end{array}$ & $\begin{array}{l}0.329 \\
(1.45)\end{array}$ & $\begin{array}{c}0.087 * * * \\
(3.01)\end{array}$ & $\begin{array}{c}0.531 * * \\
(2.41)\end{array}$ \\
\hline Loss & $\begin{array}{c}-0.042 * * \\
(-2.18)\end{array}$ & $\begin{array}{c}-0.154 * * \\
(-2.11)\end{array}$ & $\begin{array}{l}-0.008 \\
(-0.16)\end{array}$ & $\begin{array}{l}0.054 \\
(0.45)\end{array}$ & $\begin{array}{l}-0.024 \\
(-0.64)\end{array}$ & $\begin{array}{l}0.022 \\
(0.22)\end{array}$ & $\begin{array}{l}-0.006 \\
(-0.09)\end{array}$ & $\begin{array}{l}0.004 \\
(0.02)\end{array}$ & $\begin{array}{l}-0.004 \\
(-0.12)\end{array}$ & $\begin{array}{l}0.006 \\
(0.04)\end{array}$ \\
\hline Highly ranked underwriter & $\begin{array}{c}0.047 * * * \\
(2.60)\end{array}$ & $\begin{array}{l}-0.012 \\
(-0.21)\end{array}$ & $\begin{array}{l}0.038 \\
(1.13)\end{array}$ & $\begin{array}{l}-0.021 \\
(-0.24)\end{array}$ & $\begin{array}{c}0.079 * * \\
(2.53)\end{array}$ & $\begin{array}{l}0.033 \\
(0.31)\end{array}$ & $\begin{array}{l}0.065 \\
(1.60)\end{array}$ & $\begin{array}{l}0.004 \\
(0.03)\end{array}$ & $\begin{array}{c}0.072 * * \\
(2.55)\end{array}$ & $\begin{array}{l}0.148 \\
(0.79)\end{array}$ \\
\hline Big6 auditor & $\begin{array}{l}0.015 \\
(0.52)\end{array}$ & $\begin{array}{l}0.035 \\
(0.55)\end{array}$ & $\begin{array}{l}0.041 \\
(0.77)\end{array}$ & $\begin{array}{l}0.208 \\
(1.55)\end{array}$ & $\begin{array}{l}0.019 \\
(0.56)\end{array}$ & $\begin{array}{l}0.092 \\
(0.91)\end{array}$ & $\begin{array}{l}0.023 \\
(0.32)\end{array}$ & $\begin{array}{l}0.188 \\
(1.00)\end{array}$ & $\begin{array}{l}0.031 \\
(0.84)\end{array}$ & $\begin{array}{l}0.074 \\
(0.45)\end{array}$ \\
\hline Venture capitalist & $\begin{array}{c}-0.056 * * * \\
(-4.12)\end{array}$ & $\begin{array}{c}-0.155^{* *} \\
(-2.36)\end{array}$ & $\begin{array}{c}-0.074 * * \\
(-2.10)\end{array}$ & $\begin{array}{l}-0.112 \\
(-1.03)\end{array}$ & $\begin{array}{c}-0.061 * * * \\
(-2.93)\end{array}$ & $\begin{array}{c}-0.167 * * \\
(-2.00)\end{array}$ & $\begin{array}{c}-0.130 * * \\
(-2.39)\end{array}$ & $\begin{array}{c}-0.282^{*} \\
(-1.66)\end{array}$ & $\begin{array}{c}-0.063 * * * \\
(-2.99)\end{array}$ & $\begin{array}{c}-0.310 * * \\
(-2.10)\end{array}$ \\
\hline Industry-adjusted ROA & $\begin{array}{l}-0.006 \\
(-0.52)\end{array}$ & $\begin{array}{c}-0.717 * * * \\
(-9.99)\end{array}$ & $\begin{array}{l}0.036 \\
(1.22)\end{array}$ & $\begin{array}{c}-0.424 * * * \\
(-3.54)\end{array}$ & $\begin{array}{l}0.010 \\
(0.27)\end{array}$ & $\begin{array}{c}-0.242 * \\
(-1.72)\end{array}$ & $\begin{array}{c}0.088^{*} \\
(1.74)\end{array}$ & $\begin{array}{l}-0.209 \\
(-1.10)\end{array}$ & $\begin{array}{l}0.037^{*} \\
(1.67)\end{array}$ & $\begin{array}{l}-0.082 \\
(-0.57)\end{array}$ \\
\hline CAPEX & $\begin{array}{l}-0.001 \\
(-1.37)\end{array}$ & $\begin{array}{c}0.017 * * * \\
(2.76)\end{array}$ & $\begin{array}{c}-0.074 * * * \\
(-3.01)\end{array}$ & $\begin{array}{c}0.174 * \\
(1.74)\end{array}$ & $\begin{array}{c}-0.015^{* *} \\
(-2.15)\end{array}$ & $\begin{array}{l}-0.022 \\
(-0.80)\end{array}$ & $\begin{array}{c}-0.099^{*} \\
(-1.91)\end{array}$ & $\begin{array}{l}0.071 \\
(0.36)\end{array}$ & $\begin{array}{c}-0.003^{*} \\
(-1.70)\end{array}$ & $\begin{array}{c}0.023 * * \\
(2.02)\end{array}$ \\
\hline Intercept & $\begin{array}{c}-0.291 * * * \\
(-4.83)\end{array}$ & $\begin{array}{l}-0.074 \\
(-0.28)\end{array}$ & $\begin{array}{l}-0.126 \\
(-0.62)\end{array}$ & $\begin{array}{l}0.264 \\
(0.61)\end{array}$ & $\begin{array}{c}-0.266 * * * \\
(-3.15)\end{array}$ & $\begin{array}{l}-0.319 \\
(-1.04)\end{array}$ & $\begin{array}{l}-0.087 \\
(-0.32)\end{array}$ & $\begin{array}{l}1.051^{*} \\
(1.84)\end{array}$ & $\begin{array}{c}-0.275^{* * * *} \\
(-3.61)\end{array}$ & $\begin{array}{l}-0.809 \\
(-1.29)\end{array}$ \\
\hline Industry fraction & $\begin{array}{c}0.894 * * * \\
(3.74)\end{array}$ & & $\begin{array}{l}0.925^{*} \\
(1.94)\end{array}$ & & $\begin{array}{c}1.034 * * * \\
(2.75)\end{array}$ & & $\begin{array}{c}1.355^{* *} \\
(2.20)\end{array}$ & & $\begin{array}{c}0.707 * * \\
(2.09)\end{array}$ & \\
\hline Industry profitability & $\begin{array}{l}-0.055 \\
(-0.77)\end{array}$ & & $\begin{array}{l}0.131 \\
(0.96)\end{array}$ & & $\begin{array}{l}-0.063 \\
(-0.46)\end{array}$ & & $\begin{array}{l}-0.077 \\
(-0.38)\end{array}$ & & $\begin{array}{l}-0.053 \\
(-0.46)\end{array}$ & \\
\hline Industry risk & $\begin{array}{c}-0.001 * \\
(-1.71)\end{array}$ & & $\begin{array}{l}0.001 \\
(0.26)\end{array}$ & & $\begin{array}{l}0.000 \\
(0.08)\end{array}$ & & $\begin{array}{l}0.000 \\
(0.02)\end{array}$ & & $\begin{array}{l}-0.000 \\
(-0.20)\end{array}$ & \\
\hline $\begin{array}{l}\text { Durbin-Wu-Hausman test } \\
\text { against } H_{0} \text { : variables are } \\
\text { exogenous ( } \mathrm{p} \text {-value) }\end{array}$ & & 0.079 & & 0.004 & & 0.000 & & 0.002 & & 0.000 \\
\hline Number of observations & 1,037 & 1,037 & 361 & 361 & 544 & 544 & 266 & 266 & 610 & 610 \\
\hline
\end{tabular}

Table 4 presents the regression analyses of the association between real earnings management and credit ratings using three estimation approaches: Heckman two-step treatment effect model, maximum likelihood estimation (MLE) treatment effect model, and instrumental variable (IV) model. In the selection equation, rating existence is regressed on industry fraction, industry profitability, and industry risk. Industry fraction is the logarithm of one plus the percentage of firms having credit ratings in the same three-digit SIC industry as the IPO firm. Industry profitability is the median ratio of earnings before interest, taxes, depreciation and amortization (EBITDA) to total assets of firms in the same three-digit SIC industry as the IPO firm. Industry risk is the standard 
deviation of the ratio of earnings before interest, taxes, depreciation and amortization (EBITDA) to total assets of firms in the same three-digit SIC industry as the IPO firm. The outcome equation is:

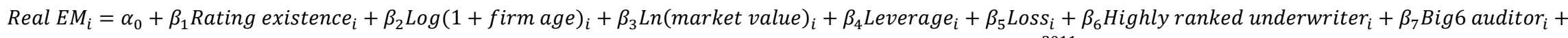
$\beta_{8}$ Venture capitalist $i+\beta_{9}$ Industry adjusted $R O A_{i}+\beta_{10}$ CAPEX $_{i}+\sum_{1991}^{2011} \beta$ Year $+\varepsilon_{i}$

The dependent variable Real EM is abnormal cash flow from operations, abnormal production costs, abnormal discretionary expenses, REM1 (the sum of abnormal production costs and abnormal discretionary expenses), or REM2 (the sum of abnormal cash flow from operations and abnormal discretionary expenses) in the offering year. Abnormal cash flow from operations, abnormal production costs, abnormal discretionary expenses are estimated using models developed by Dechow et al. (1998) and implemented by Roychowdhury (2006). Abnormal cash flows from operations and abnormal discretionary expenses are multiplied by minus one so that accrual-based and real earnings management proxies have the same interpretation. REM1 is the sum of abnormal production costs and abnormal discretionary expenses, and REM2 is the sum of abnormal cash flow from operations and abnormal discretionary expenses. Rating existence equals to one if the firm has a credit rating one month prior to the offering, and zero otherwise. $\log (1+$ firm age $)$ is the logarithm of one plus firm age in the offering year. Ln(market value) is the natural logarithm of the firm's market value at the time of the listing. Leverage is the ratio of total liabilities to total assets. Loss equals to one if the firm has negative earnings before interest and taxes in the fiscal year prior to the offering, and zero otherwise. Highly ranked underwriter equals to one if the firm is underwritten by an underwriter which has a ranking score of 9.0 or above according to the underwriter rankings retrieved from Jay Ritter's webpage, and zero otherwise. Big6 auditor equals to one if the firm is audited by a big six accounting firm (i.e., Arthur Andersen, Coopers \& Lybrand, Ernst \& Young, Deloitte \& Touche, KPMG, and PricewaterhouseCoopers), and zero otherwise. Venture capitalist equals to one if the firm is venture backed, and zero otherwise. Industry-adjusted ROA is the firm's ROA adjusted for the industry's median ROA. CAPEX is the average capital expenditures in the offering year and one year after scaled by total assets at the beginning of the offering year. All regressions control for year fixed effects whose coefficients are suppressed. One, two and three asterisks denote statistical significance at the $10 \%, 5 \%$ and $1 \%$ levels, respectively. The test statistics are shown in parentheses below coefficient estimates. Standard errors are adjusted for heteroskedasticity. 
Table 5

Analyses of post-issue accounting performance

Panel A: Analvses of post-issue CFO

Dependent variable: Cash flow from operations

\begin{tabular}{|c|c|c|c|c|c|c|}
\hline & Abnormal accruals & $\begin{array}{l}\text { Abnormal cash flow } \\
\text { from operations }\end{array}$ & $\begin{array}{c}\text { Abnormal production } \\
\text { costs }\end{array}$ & $\begin{array}{c}\text { Abnormal discretionary } \\
\text { expenses }\end{array}$ & REM1 & REM2 \\
\hline EM & $\begin{array}{l}-0.034 \\
(-1.19)\end{array}$ & $\begin{array}{l}-0.044 \\
(-1.51)\end{array}$ & $\begin{array}{l}0.035 \\
(1.31)\end{array}$ & $\begin{array}{c}-0.059 * * * \\
(-2.65)\end{array}$ & $\begin{array}{l}-0.026 \\
(-1.23)\end{array}$ & $\begin{array}{l}-0.032 \\
(-1.31)\end{array}$ \\
\hline EM*Rating existence & $\begin{array}{c}0.146^{* * * *} \\
(2.59)\end{array}$ & $\begin{array}{c}0.319^{* *} \\
(2.26)\end{array}$ & $\begin{array}{c}0.230^{* * * *} \\
(2.96)\end{array}$ & $\begin{array}{c}0.202 * * * \\
(3.16)\end{array}$ & $\begin{array}{c}0.131 * * * \\
(2.71)\end{array}$ & $\begin{array}{c}0.293 * * * \\
(3.68)\end{array}$ \\
\hline $\mathrm{CFO}$ & $\begin{array}{c}0.044 * * \\
(2.15)\end{array}$ & $\begin{array}{c}0.062 * * * \\
(2.93)\end{array}$ & $\begin{array}{c}0.172^{* * * *} \\
(6.63)\end{array}$ & $\begin{array}{c}0.047 * * \\
(1.99)\end{array}$ & $\begin{array}{c}0.156^{* * * *} \\
(6.38)\end{array}$ & $\begin{array}{l}0.056^{*} \\
(1.66)\end{array}$ \\
\hline CAPEX & 0.005 & $\begin{array}{c}0.009 * * \\
(2.46)\end{array}$ & $\begin{array}{c}-0.093^{*} \\
(-1.92)\end{array}$ & $\begin{array}{l}0.038 \\
(1.53)\end{array}$ & -0.069 & 0.029 \\
\hline Intercept & $\begin{array}{l}1 \\
0.031 \\
(0.94)\end{array}$ & $\begin{array}{c}-0.131 * * \\
(-2.24)\end{array}$ & $\begin{array}{l}-1.92) \\
-0.010 \\
(-0.57)\end{array}$ & $\begin{array}{l}(1.021 \\
-0.021 \\
(-0.35)\end{array}$ & $\begin{array}{l}-1.031) \\
-0.028 \\
(-0.37)\end{array}$ & $\begin{array}{l}(1.03) \\
-0.034 \\
(-0.68)\end{array}$ \\
\hline $\begin{array}{l}\text { P-value of F-test }[\mathrm{EM}+ \\
\text { EM*Rating existence }=0]\end{array}$ & 0.035 & 0.058 & 0.001 & 0.025 & 0.041 & 0.001 \\
\hline R-squared & 0.172 & 0.279 & 0.547 & 0.281 & 0.545 & 0.227 \\
\hline Number of observations & 1,125 & 1,152 & 393 & 601 & 288 & 676 \\
\hline
\end{tabular}

Panel B: Analvses of post-issue ROA

Dependent variable: ROA

\begin{tabular}{|c|c|c|c|c|c|c|}
\hline & Abnormal accruals & $\begin{array}{l}\text { Abnormal cash flow } \\
\text { from operations }\end{array}$ & $\begin{array}{c}\text { Abnormal production } \\
\text { costs }\end{array}$ & $\begin{array}{c}\text { Abnormal discretionary } \\
\text { expenses }\end{array}$ & REM1 & REM2 \\
\hline EM & $\begin{array}{c}-0.080 * \\
(-1.73)\end{array}$ & $\begin{array}{c}-0.061 * \\
(-1.92)\end{array}$ & $\begin{array}{l}-0.019 \\
(-0.57)\end{array}$ & $\begin{array}{c}-0.087 * * \\
(-2.15)\end{array}$ & $\begin{array}{l}-0.032 \\
(-1.32)\end{array}$ & $\begin{array}{l}-0.024 \\
(-0.68)\end{array}$ \\
\hline EM*Rating existence & $0.214 * * *$ & $0.453 * * *$ & $0.255^{* * * *}$ & $0.200 * *$ & $0.186^{* * * *}$ & $0.319^{* * *}$ \\
\hline & $(2.66)$ & (3.44) & $(2.67)$ & $(2.14)$ & $(2.96)$ & (3.26) \\
\hline ROA & 0.042 & $0.055 * * *$ & $0.072 * * *$ & 0.022 & $0.064 * * *$ & $0.040 *$ \\
\hline & $(1.38)$ & $(4.75)$ & $(4.82)$ & $(1.41)$ & $(9.55)$ & (1.87) \\
\hline CAPEX & 0.016 & $0.024 * * *$ & $-0.182 * *$ & 0.023 & -0.047 & $0.016^{* *}$ \\
\hline & $\begin{array}{l}(1.13) \\
-0.050\end{array}$ & $\begin{array}{c}(3.82) \\
-0.127 * *\end{array}$ & $\begin{array}{c}(-2.54) \\
-0.125 * * *\end{array}$ & $\begin{array}{l}(1.36) \\
-0.012\end{array}$ & $\begin{array}{l}(-1.20) \\
-0.121\end{array}$ & $\begin{array}{c}(2.35) \\
-0.151 * *\end{array}$ \\
\hline & $(-1.37)$ & $(-2.28)$ & $(-5.80)$ & $(-0.18)$ & $(-1.33)$ & $(-2.39)$ \\
\hline $\begin{array}{l}\text { P-value of F-test }[\mathrm{EM}+ \\
\text { EM } * \text { Rating existence }=0]\end{array}$ & 0.055 & 0.004 & 0.018 & 0.201 & 0.016 & 0.004 \\
\hline R-squared & 0.224 & 0.287 & 0.528 & 0.240 & 0.610 & 0.299 \\
\hline Number of observations & 1,125 & 1,152 & 393 & 601 & 288 & 676 \\
\hline
\end{tabular}

Table 5 presents the regression analyses of the association between at-issue earnings management and post-issue accounting performance. The regression equations are:

$$
C F O_{i, t=1}=\alpha_{0}+\beta_{1} E M_{i, t=0}+\beta_{2} E M_{i, t=0} * \text { Rating existence } e_{i, t=0}+\beta_{3} C F O_{i, t=0}+\beta_{4} C A P E X_{i, t=0}+\sum \beta \text { Industry }+\sum_{1991}^{2011} \beta Y e a r+\varepsilon_{i}
$$




$$
R O A_{i, t=1}=\alpha_{0}+\beta_{1} E M_{i, t=0}+\beta_{2} E M_{i, t=0} * \text { Rating existence } e_{i, t=0}+\beta_{3} R O A_{i, t=0}+\beta_{4} C A P E X_{i, t=0}+\sum \beta \text { Industry }+\sum_{1991}^{2011} \beta Y \text { ear }+\varepsilon_{i}
$$

The dependent variable $C F O$ is the cash flow from operations scaled by lagged total assets in the fiscal year following the offering, and $R O A$ is the net income scaled by lagged total assets in the fiscal year following the offering. EM is the positive value of abnormal accruals, abnormal cash flow from operations, abnormal production costs, abnormal discretionary expenses, REM1, or REM2. Abnormal accruals are estimated using the modified Jones (1991) model and adjusted for the abnormal accruals of a performance-matched non-IPO firm following Kothari et al. (2005). Abnormal cash flow from operations, abnormal production costs, abnormal discretionary expenses are estimated using models developed by Dechow et al. (1998) and implemented by Roychowdhury (2006). Abnormal cash flows from operations and abnormal discretionary expenses are multiplied by minus one so that accrual-based and real earning management proxies have the same interpretation. REM1 is the sum of abnormal production costs and abnormal discretionary expenses, and REM2 is the sum of abnormal cash flow from operations and abnormal discretionary expenses. Rating existence equals to one if the firm has a credit rating one month prior to the offering, and zero otherwise. CAPEX is the average capital expenditures in the offering year and one year after scaled by total assets at the beginning of the offering year. All regressions control for year and industry fixed effects whose coefficients are suppressed. One, two and three asterisks denote the statistical significance at the $10 \%, 5 \%$ and $1 \%$ levels, respectively. The test statistics are shown in parentheses below coefficient estimates. Standard errors are adjusted for heteroskedasticity. 
Table 6

Analyses of post-issue long-run stock performance

Panel A: Analyses of post-issue long-run stock performance - Event-time approach

Dependent variable: Post-issue three-year buy-and-hold abnormal returns (BHARs)

\begin{tabular}{|c|c|c|c|c|c|c|}
\hline & Abnormal accruals & $\begin{array}{l}\text { Abnormal cash flow } \\
\text { from operations }\end{array}$ & $\begin{array}{l}\text { Abnormal production } \\
\text { costs }\end{array}$ & $\begin{array}{l}\text { Abnormal discretionary } \\
\text { expenses }\end{array}$ & REM1 & REM2 \\
\hline \multirow[t]{2}{*}{ EM } & $-0.203^{*}$ & $-0.093^{*}$ & $-0.222 * *$ & 0.015 & -0.133 & -0.059 \\
\hline & $(-1.80)$ & $(-1.67)$ & $(-2.18)$ & $(0.13)$ & $(-0.95)$ & $(-0.56)$ \\
\hline \multirow[t]{2}{*}{ EM*Rating existence } & $1.224^{*}$ & 0.331 & 0.007 & 0.489 & 0.049 & 0.359 \\
\hline & $(1.90)$ & $(0.63)$ & $(0.02)$ & $(1.29)$ & $(0.21)$ & (1.09) \\
\hline \multirow[t]{2}{*}{ Underpricing } & -0.137 & $-0.236 * *$ & 0.075 & -0.234 & 0.215 & -0.309 \\
\hline & $(-0.95)$ & $(-2.05)$ & $(0.18)$ & $(-0.87)$ & $(0.34)$ & $(-1.36)$ \\
\hline \multirow[t]{2}{*}{$\log (1+$ firm age $)$} & -0.134 & -0.078 & 0.088 & -0.025 & $0.309^{*}$ & -0.170 \\
\hline & $(-1.22)$ & $(-0.71)$ & $(0.50)$ & $(-0.18)$ & $(1.89)$ & $(-1.18)$ \\
\hline \multirow[t]{2}{*}{ Market BHR } & 0.121 & $0.481 * *$ & 0.567 & -0.165 & -0.004 & 0.351 \\
\hline & $(0.57)$ & $(2.02)$ & $(1.31)$ & $(-0.53)$ & $(-0.01)$ & (1.11) \\
\hline \multirow{2}{*}{ Book-to-market } & 0.179 & 0.117 & -0.097 & -0.037 & -0.125 & 0.099 \\
\hline & (1.53) & (1.04) & $(-0.61)$ & $(-0.31)$ & $(-0.63)$ & $(0.85)$ \\
\hline \multirow[t]{2}{*}{$\operatorname{Ln}$ (market value) } & 0.005 & -0.041 & -0.056 & 0.039 & -0.075 & 0.027 \\
\hline & $(0.11)$ & $(-1.01)$ & $(-0.86)$ & $(0.67)$ & $(-0.94)$ & $(0.49)$ \\
\hline \multirow[t]{2}{*}{ ROA } & 0.012 & -0.018 & -0.000 & $0.027 *$ & 0.014 & $0.028 *$ \\
\hline & (1.34) & $(-0.62)$ & $(-0.01)$ & $(1.75)$ & $(1.00)$ & $(1.80)$ \\
\hline \multirow[t]{2}{*}{ Highly ranked underwriter } & 0.033 & 0.038 & -0.060 & -0.024 & -0.073 & 0.071 \\
\hline & $(0.33)$ & $(0.40)$ & $(-0.45)$ & $(-0.20)$ & $(-0.49)$ & $(0.56)$ \\
\hline \multirow[t]{2}{*}{ Big6 auditor } & $0.341 * * *$ & $0.418 * * *$ & 0.318 & $0.265^{*}$ & 0.388 & $0.308 * *$ \\
\hline & $(3.07)$ & $(3.27)$ & $(1.20)$ & $(1.74)$ & $(1.54)$ & $(2.47)$ \\
\hline \multirow[t]{2}{*}{ High-tech industry } & $0.275 * * *$ & $0.192 *$ & 0.115 & 0.244 & 0.107 & $0.308^{*}$ \\
\hline & $(2.70)$ & $(1.94)$ & $(0.71)$ & $(1.63)$ & $(0.60)$ & $(1.92)$ \\
\hline \multirow[t]{2}{*}{ Intercept } & $-0.673 * *$ & $-0.914 * *$ & -0.438 & -0.251 & 0.087 & $-0.887^{*}$ \\
\hline & $(-2.02)$ & $(-2.48)$ & $(-0.64)$ & $(-0.51)$ & $(0.12)$ & $(-1.95)$ \\
\hline $\begin{array}{l}\text { P-value of F-test }[E M+ \\
\text { EM*Rating existence }=0]\end{array}$ & 0.114 & 0.653 & 0.572 & 0.211 & 0.766 & 0.397 \\
\hline R-squared & 0.086 & 0.056 & 0.115 & 0.079 & 0.174 & 0.059 \\
\hline Number of observations & 1,087 & 1,122 & 393 & 574 & 286 & 642 \\
\hline
\end{tabular}




\begin{tabular}{|c|c|c|c|c|c|c|}
\hline & Abnormal accruals & $\begin{array}{l}\text { Abnormal cash flow } \\
\text { from operations }\end{array}$ & $\begin{array}{l}\text { Abnormal production } \\
\text { costs }\end{array}$ & $\begin{array}{c}\text { Abnormal discretionary } \\
\text { expenses }\end{array}$ & REM1 & REM2 \\
\hline \multicolumn{7}{|l|}{ Fama-French three-factor model } \\
\hline Without credit ratings & $\begin{array}{c}-0.007 * * * \\
(-2.90)\end{array}$ & $\begin{array}{l}-0.004 * \\
(-1.74)\end{array}$ & $\begin{array}{l}-0.004 \\
(-1.35)\end{array}$ & $\begin{array}{l}-0.001 \\
(-0.53)\end{array}$ & $\begin{array}{l}-0.004 \\
(-1.24)\end{array}$ & $\begin{array}{l}-0.003 \\
(-1.26)\end{array}$ \\
\hline With credit ratings & $\begin{array}{l}0.001 \\
(0.23)\end{array}$ & $\begin{array}{l}-0.001 \\
(-0.18)\end{array}$ & $\begin{array}{c}-0.010^{*} \\
(-1.81)\end{array}$ & $\begin{array}{l}0.004 \\
(0.80)\end{array}$ & $\begin{array}{l}-0.003 \\
(-0.53)\end{array}$ & $\begin{array}{l}0.002 \\
(0.26)\end{array}$ \\
\hline \multicolumn{7}{|l|}{ Carhart four-factor model } \\
\hline Without credit ratings & $\begin{array}{c}-0.006 * * \\
(-2.36)\end{array}$ & $\begin{array}{c}-0.004^{*} \\
(-1.82)\end{array}$ & $\begin{array}{l}-0.004 \\
(-1.59)\end{array}$ & $\begin{array}{l}-0.002 \\
(-0.65)\end{array}$ & $\begin{array}{l}-0.004 \\
(-1.47)\end{array}$ & $\begin{array}{l}-0.004 \\
(-1.55)\end{array}$ \\
\hline With credit ratings & $\begin{array}{l}0.003 \\
(0.45)\end{array}$ & $\begin{array}{l}-0.004 \\
(-0.56)\end{array}$ & $\begin{array}{c}-0.011 * \\
(-1.93)\end{array}$ & $\begin{array}{l}0.002 \\
(0.42)\end{array}$ & $\begin{array}{l}-0.007 \\
(-0.96)\end{array}$ & $\begin{array}{l}-0.003 \\
(-0.45)\end{array}$ \\
\hline
\end{tabular}

Table 6 presents the regression analyses of the association between at-issue earnings management and post-issue long-run stock performance.

Panel A shows the regression analyses of long-run stock performance over the three-year post-issue period. The regression equation is:

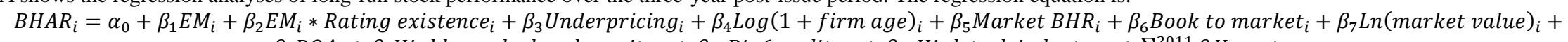
$\beta_{8}$ ROA $_{i}+\beta_{9}$ Highly ranked underwriter $r_{i}+\beta_{10}$ Big6 auditor $_{i}+\beta_{11}$ High tech industry $_{i}+\sum_{1991}^{2011} \beta$ Year $+\varepsilon_{i}$

The dependent variable BHAR is the firm's post-issue three-year buy-and-hold abnormal return calculated starting from the day after the annual financial report date in the offering year to the earlier of the three year anniversary date or the delisting date. EM is the positive value of abnormal accruals, abnormal cash flow from operations, abnormal production costs, abnormal discretionary expenses, REM1, or REM2. Abnormal accruals are estimated using the modified Jones (1991) model and adjusted for the abnormal accruals of a performance-matched nonIPO firm following Kothari et al. (2005). Abnormal cash flow from operations, abnormal production costs, abnormal discretionary expenses are estimated using models developed by Dechow et al. (1998) and implemented by Roychowdhury (2006). Abnormal cash flows from operations and abnormal discretionary expenses are multiplied by minus one so that accrualbased and real earnings management proxies have the same interpretation. REMl is the sum of abnormal production costs and abnormal discretionary expenses, and $R E M 2$ is the sum of abnormal cash flow from operations and abnormal discretionary expenses. Rating existence equals to one if the firm has a credit rating one month prior to the offering, and zero otherwise. Underpricing is the firm's initial returns on the first trading day. Log $(1+$ firm age $)$ is the logarithm of one plus firm age in in offering year. Market BHR is the three-year buy-and-hold value weighted market index return. Book to market is the ratio of book value to market value at the end of the fiscal year of the offering. Ln(market value) is the natural logarithm of the firm's market value at the time of the listing. ROA is the net income scaled by lagged total assets in the offering year. Highly ranked underwriter equals to one if the firm is underwritten by an underwriter which has a ranking score of 9.0 or above according to the underwriter rankings retrieved from Jay Ritter's webpage, and zero otherwise. Big6 auditor equals to one if the firm is audited by a big six accounting firm (i.e., Arthur Andersen, Coopers \& Lybrand, Ernst \& Young, Deloitte \& Touche, KPMG, and PricewaterhouseCoopers), and zero otherwise. High tech industry equals to one if the firm is in the high-tech industry, and zero otherwise. All regressions control for year fixed effects whose coefficients are suppressed. One, two and three asterisks denote the statistical significance at the $10 \%, 5 \%$ and $1 \%$ levels, respectively. The test statistics are shown in parentheses below coefficient estimates. Standard errors are adjusted for heteroskedasticity.

Panel B shows the analyses of long-run abnormal stock returns from going long IPOs with upward earnings management and short IPOs with downward earnings management. The regression equation is:

POSEM $M_{p t}-N E G E M_{p t}=\alpha_{p}+\beta_{m} M K T_{t}+\beta_{s} S M B_{t}+\beta_{h} H M L_{t}+\varepsilon_{t}$

POSEM - NEGEM is the return from taking a long position in a portfolio of IPO firms that manage earnings upward and a short position in a portfolio of IPO firms that manage earnings downward for each calendar month in the sample period. $M K T$ is the excess monthly return on the value-weighted CRSP index for each calendar month in the sample period. SMB is the difference in the returns of value-weighted portfolios of small and large stocks for each calendar month in the sample period. $H M L$ is the difference in the returns of value-weighted portfolios of high book-to-market and low book-to-market stocks for each calendar month in the sample period. The IPO firm's returns are included in the portfolio returns for the period of three years after the IPO fiscal year end. The Carhart four-factor model adds to the Fama and French three-factor model an additional factor to account for one-year momentum price return. The factors for those models are retrieved from Professor Kenneth French's website. 
Table 7

Analyses of interaction effects between credit rating agencies and venture capitalists, top-tier investment banks, and Big Six auditors

Panel A: Interaction effect between credit rating agencies and venture capitalists

\begin{tabular}{|c|c|c|c|c|c|c|}
\hline & $\begin{array}{l}\text { Abnormal } \\
\text { accruals }\end{array}$ & $\begin{array}{l}\text { Abnormal cash flow } \\
\text { from operations }\end{array}$ & $\begin{array}{c}\text { Abnormal } \\
\text { production costs }\end{array}$ & $\begin{array}{l}\text { Abnormal discretionary } \\
\text { expenses }\end{array}$ & REM1 & REM2 \\
\hline Rating existence & $\begin{array}{c}-1.271^{* *} \\
(-2.00)\end{array}$ & $\begin{aligned}-1.628^{*} \\
(-1.76)\end{aligned}$ & $\begin{array}{c}-1.088^{*} \\
(-1.87)\end{array}$ & $\begin{array}{c}-2.136 * * \\
(-2.53)\end{array}$ & $\begin{array}{c}-1.347 * * \\
(-2.19)\end{array}$ & $\begin{array}{c}-3.456^{* *} \\
(-2.47)\end{array}$ \\
\hline Venture capitalist & $\begin{array}{c}-0.126^{* *} \\
(-2.51)\end{array}$ & $\begin{array}{c}-0.188^{* *} \\
(-2.27)\end{array}$ & $\begin{array}{l}-0.128 \\
(-1.11)\end{array}$ & $\begin{array}{c}-0.222 * * \\
(-2.35)\end{array}$ & $\begin{array}{c}-0.313^{*} \\
(-1.77)\end{array}$ & $\begin{array}{c}-0.367 * * \\
(-2.54)\end{array}$ \\
\hline Rating existence $*$ Venture capitalist & $\begin{array}{l}1.044 * \\
(1.78)\end{array}$ & $\begin{array}{l}1.355^{*} \\
(1.69)\end{array}$ & $\begin{array}{c}0.935^{*} \\
(1.73)\end{array}$ & $\begin{array}{c}1.910^{* *} \\
(2.49)\end{array}$ & $\begin{array}{l}1.007 * \\
(1.79)\end{array}$ & $\begin{array}{c}2.861^{* *} \\
(2.40)\end{array}$ \\
\hline $\begin{array}{l}\text { P-value of F-test }[\text { Rating existence }+ \text { Rating } \\
\text { existence*Venture capitalist }=0]\end{array}$ & 0.012 & 0.067 & 0.266 & 0.295 & 0.134 & 0.066 \\
\hline Number of observations & 1,000 & 1,037 & 361 & 544 & 266 & 610 \\
\hline
\end{tabular}

Panel B: Interaction effect between credit rating agencies and top-tier underwriters

\begin{tabular}{|c|c|c|c|c|c|c|}
\hline & $\begin{array}{l}\text { Abnormal } \\
\text { accruals }\end{array}$ & $\begin{array}{l}\text { Abnormal cash flow } \\
\text { from operations }\end{array}$ & $\begin{array}{c}\text { Abnormal } \\
\text { production costs }\end{array}$ & $\begin{array}{l}\text { Abnormal discretionary } \\
\text { expenses }\end{array}$ & REM1 & REM2 \\
\hline Rating existence & $\begin{array}{c}-2.596 * * \\
(-2.10)\end{array}$ & $\begin{array}{l}-3.871 \\
(-1.33)\end{array}$ & $\begin{array}{l}0.448 \\
(0.64)\end{array}$ & $\begin{array}{l}-1.360 \\
(-1.31)\end{array}$ & $\begin{array}{l}-0.617 \\
(-0.63)\end{array}$ & $\begin{array}{l}-2.336 \\
(-1.06)\end{array}$ \\
\hline Highly ranked underwriter & $\begin{array}{c}-0.153 * * \\
(-2.43)\end{array}$ & $\begin{array}{r}-0.242 * \\
(-1.82)\end{array}$ & $\begin{array}{l}-0.037 \\
(-0.40)\end{array}$ & $\begin{array}{c}-0.218^{* *} \\
(-2.47)\end{array}$ & $\begin{array}{l}-0.171 \\
(-1.22)\end{array}$ & $\begin{array}{l}-0.294^{*} \\
(-1.96)\end{array}$ \\
\hline Rating existence $*$ Highly ranked underwriter & $\begin{array}{c}2.384 * * \\
(1.98)\end{array}$ & $\begin{array}{l}3.540 \\
(1.27)\end{array}$ & $\begin{array}{l}-0.489 \\
(-0.73)\end{array}$ & $\begin{array}{l}1.164 \\
(1.17)\end{array}$ & $\begin{array}{l}0.469 \\
(0.51)\end{array}$ & $\begin{array}{l}2.088 \\
(0.98)\end{array}$ \\
\hline $\begin{array}{l}\text { P-value of F-test [Rating existence }+ \text { Rating existence* } \\
\text { Highly ranked underwriter }=0 \text { ] }\end{array}$ & 0.001 & 0.027 & 0.618 & 0.011 & 0.250 & 0.034 \\
\hline Number of observations & 1,000 & 1,037 & 361 & 544 & 266 & 610 \\
\hline
\end{tabular}


Panel C: Interaction effect between credit rating agencies and Big Six auditors

\begin{tabular}{|c|c|c|c|c|c|c|}
\hline & $\begin{array}{l}\text { Abnormal } \\
\text { accruals }\end{array}$ & $\begin{array}{l}\text { Abnormal cash flow } \\
\text { from operations }\end{array}$ & $\begin{array}{c}\text { Abnormal } \\
\text { production costs }\end{array}$ & $\begin{array}{l}\text { Abnormal discretionary } \\
\text { expenses }\end{array}$ & REM1 & REM2 \\
\hline Rating existence & $\begin{array}{l}-9.104 \\
(-1.10)\end{array}$ & $\begin{array}{c}-11.382 \\
(-0.91)\end{array}$ & $\begin{array}{l}6.351 \\
(0.99)\end{array}$ & $\begin{array}{c}-19.558 \\
(-1.46)\end{array}$ & $\begin{array}{l}-0.862 \\
(-0.31)\end{array}$ & $\begin{array}{r}-12.664 \\
(-1.20)\end{array}$ \\
\hline Big6 auditor & $\begin{array}{l}-0.315 \\
(-1.25)\end{array}$ & $\begin{array}{l}-0.605 \\
(-0.96)\end{array}$ & $\begin{array}{l}0.564 \\
(1.61)\end{array}$ & $\begin{array}{c}-0.845^{* * *} \\
(-2.80)\end{array}$ & $\begin{array}{l}0.102 \\
(0.35)\end{array}$ & $\begin{array}{r}-0.566 \\
(-1.73)\end{array}$ \\
\hline Rating existence $*$ Big6 auditor & $\begin{array}{l}8.899 \\
(1.08)\end{array}$ & $\begin{array}{l}11.038 \\
(0.90)\end{array}$ & $\begin{array}{l}-6.362 \\
(-1.00)\end{array}$ & $\begin{array}{c}19.156 \\
(1.43)\end{array}$ & $\begin{array}{l}0.721 \\
(0.26)\end{array}$ & $\begin{array}{r}12.412 \\
(1.18)\end{array}$ \\
\hline $\begin{array}{l}\text { P-value of F-test [Rating existence + Rating existence* } \\
\text { Big6 auditor }=0 \text { ] }\end{array}$ & 0.048 & 0.093 & 0.907 & 0.001 & 0.171 & 0.025 \\
\hline Number of observations & 1,000 & 1,037 & 361 & 544 & 266 & 610 \\
\hline
\end{tabular}

Table 7 presents the results of the instrumental variable regressions that analyse the association of earnings management and credit rating existence controlling for the interaction effects between credit rating agencies and venture capitalists, reputable investment banks, and Big Six auditors. All regressions include the same set of controls as the regressions presented in Table 3 and Table 4 , but for the sake of brevity, we do not show the results of the control variables. One, two and three asterisks denote the statistical significance at the $10 \%, 5 \%$ and $1 \%$ levels, respectively. The test statistics are shown in parentheses below coefficient estimates. Standard errors are adjusted for heteroskedasticity. 